Geology of the

Eastern Part of the

Harold D. Roberts Tunnel,

Colorado

(Stations $690+00$ to $1238+58$ )

GEOLOGICAL SURVEY PROFESSIONAL PAPER 831-D 


\section{Geology of the Eastern Part of the Harold D. Roberts Tunnel, Colorado (Stations $690+00$ to $1238+58$ )}

By LAWRENCE A. WARNER and CHARLES S. ROBINSON

ENGINEERING GEOLOGY OF THE HAROLD D. ROBERTS TUNNEL, COLORADO

GEOLOGICAL SURVEY PROFESSIONAL PAPER 831-D

A description of the geology of and

engineering practices used in driving

the eastern part of the tunnel

through a sequence of almost

entirely Precambrian rocks

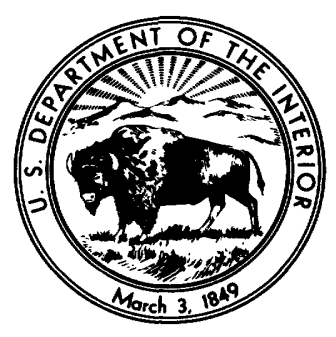




\section{UNITED STATES DEPARTMENT OF THE INTERIOR}

\section{JAMES G. WATT, Secretary}

\section{GEOLOGICAL SURVEY}

Doyle G. Frederick, Acting Director

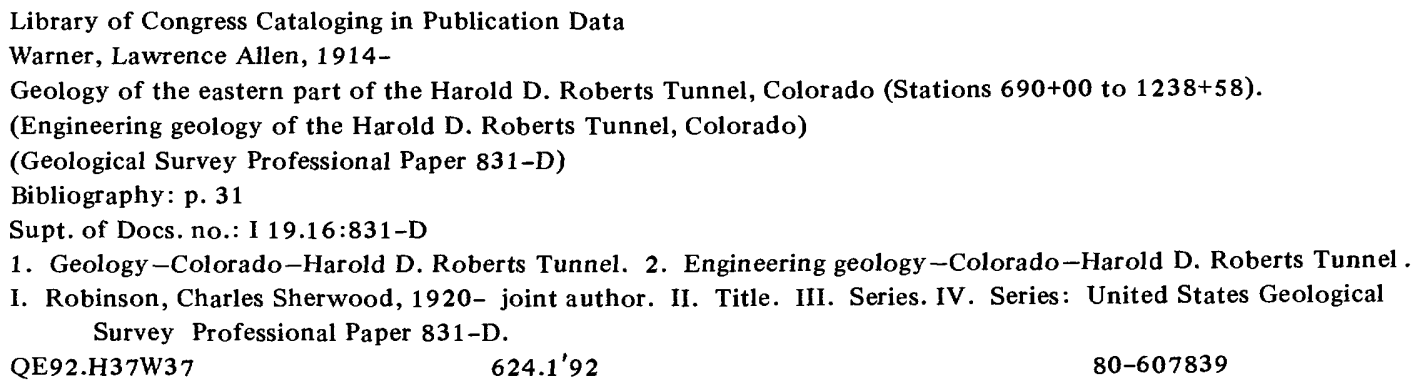

For sale by the Superintendent of Documents, U.S. Government Printing Office Washington, D.C. 20402 


\section{CONTENTS}

Abstract

\section{Introduction}

The series

History and general geology of the tunnel

General geology from station $690+00$ to the East Portal Rock units

Metasedimentary rocks

Amphibolite

Migmatite

Microcline gneiss

Biotite gneiss and schist

Igneous rocks

Boulder Creek Granite

Silver Plume Granite

Pegmatite and aplite

Structure

Augite diorite

Folds

Foliation and lineation

Faults

Joints

Engineering practices in relation to geology

\section{Stations $690+00$ to $808+00$}

Biotite Gneiss and Schist

Geology and structure

Waterflows and grouting

Supports

Overbreak

Progress

\section{Stations $808+00$ to $886+00$ North Fork Fault Zone}

Geology and structure

Waterflow

Supports

Overbreak

Progress
Page

D1

2
2
4
4
5
6
6
6
7
8
8
9
9
10
10
11

Geology and structure

Spalling and popping rock

Supports.

Overbreak

Progress

\section{Stations $886+00$ to $977+00$} Boulder Creek pluton

Page

Geology and structure

Stations $977+00$ to $1083+00$

Microcline gneiss and Migmatite

Geology and structure

17

Supports

Overbreak

Progress

\section{Stations $1083+00$ to $1238+58$ \\ Silver Plume Granite}

Engineering data

19

19

Criteria for estimating the bulk properties of rock

Geophysical parameters ............................................ 20

Engineering parameters ……............................................. 21

Geological parameters .................................................... $\quad 24$

Discussion of results

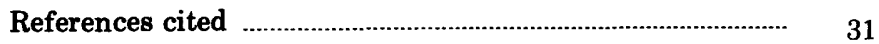

\section{ILLUSTRATIONS}

[Plates are in the pocket]

PLATE 1. Geologic plans and sections, equal-area plots of structural data, and engineering data for the Roberts Tunnel from station $690+00$ to $1238+58$, East Portal.

2. Detailed geologic plan and section, and engineering data, stations $753+00$ to $769+60$. 
Plates 3-5. Composite tunnel sections and geologic plans and sections of selected intervals in the Roberts Tunnel showing Page relation of overbreak to geology:

3. Stations $707+60$ to $864+90$.

4. Stations $890+60$ to $1005+00$.

5. Stations $1012+60$ to $1135+00$.

FIGURE 1. Index map showing location of Harold D. Roberts Tunnel

2. Generalized geologic section of the Roberts Tunnel

3-8. Diagrams showing statistical relationship of tunnel and attitudes of foliation, faults, and joints:

3. In biotite gneiss and schist between stations $690+00$ and $808+00$

4. In biotite gneiss and schist between stations $808+00$ and $886+00$

5. In Boulder Creek Granite between stations $886+00$ and $977+00$

6. In metasedimentary rocks between stations $997+00$ and $1083+00$

7. In Silver Plume Granite between station $1083+00$ and the East Portal

9-14. Graphs:

8. In metasedimentary rocks between station $1083+00$ and the East Portal

9. Relation of elastic properties, density, and porosity in Precambrian rocks

10. Percent support in relation to other engineering properties for rock units

11. Phi in relation to engineering properties of rock types

12. Rho in relation to engineering properties of rock types

13. Joint parameters in relation to percent support for rock units

14. Fault parameters in relation to percent support for rock units

\section{TABLES}

TABLE 1. Physical properties of Precambrian rocks

2. Engineering properties in relation to rock type

3. Steel supports in relation to rock units

4. Relation of planar rock fabric to engineering properties

5. Summary of fracture parameters and engineering data for rock units

\section{GLOSSARY}

“A” line. The line within which no steel support or timber support shall remain.

Arch. Curved roof of an underground opening. The part of the tunnel above the centerline.

Arching tendency. Tendency of incompetent or moderately competent rocks to form an arch above an underground opening by caving. Commonly, the arch assumes the shape of a Gothic arch in cross section.

"B" line. The line within which no unexcavated material, tamped fill, lagging, spiling, crown bars, spreaders, collar braces, or wall plates shall remain.

Bid items. Items of work listed in contract documents and serving as the basis for bids by the contractor.

Blocking. Wood blocks placed between steel supports and walls or arch of tunnel to provide support and maintain alinement of ribs.

Breast boards. Wood planking placed temporarily at tunnel heading to contain incompetent rock.

California switch. A section of movable double track permitting switching of muck cars near the tunnel heading.

Centerline. The line (in the Roberts Tunnel) at the center of the finished concrete lining of circular cross section.
Change order. Order issued to define procedures or items of work not covered in original contract documents, or order to change the provisions expressed in the original contract documents.

Collar brace. Wood or steel brace placed between or on top of sides of steel or timber sets to maintain alinement. Also called a "spreader."

Competent rock. Rock that stands without support in underground openings.

Contract drawings. Drawings included in the contract documents.

Contract specifications. Specifications for various items of construction included in the contract documents.

Crown bar. Steel rail or heavy wood plank placed on top of steel set or sets nearest heading and projecting forward to tunnel heading. Provides temporary support of rocks in arch until additional steel sets and lagging can be installed closer to the heading.

Extra work order (EWO). Order issued to contractor to perform work not originally described in the contract documents.

False set. A steel or timber set placed temporarily to expedite a tunneling operation; for example, a spiling operation. 
Feeler hole. Hole drilled from tunnel heading or elsewhere to test geologic conditions beyond heading or in rocks adjacent to an underground opening.

Footblock. Wood block serving as a support at the base of a steel rib. Block on which ribs are erected.

Grout. Mixture of cement, water, and, for special purposes, various additives. Pumped into fractured rock to fill voids, seal off water flows, and increase strength.

Gunite. Mixture of water, sand, and cement sprayed on exposed rock to provide a protective coating.

Heading. The working face at the limit of penetration of the tunnel.

Heavy ground. Ground that requires full support. Typical highly faulted or altered rock associated with intensive faulting.

Heavy rock. Rock that is intensly faulted and altered and requires full support in underground openings.

Illite. A polymorphic form of muscovite that has a two layered (2M) monoclinic form. Identified by X-ray diffraction.

Incompetent rock. Rock that will not stand in underground openings without support.

Invert. The portion of the tunnel below the centerline. The bottom or floor of a tunnel.

Invert section. The section of the tunnel below the centerline or spring line.

Invert strut. Steel or wood support across invert, or bottom of tunnel, to hold foot of legs in place or to prevent heaving of floor.

Jumbo. A movable platform on which one or more drills are mounted. Used primarily for drilling blast holes at the tunnel heading but may provide elevated work space for other operations.

Jump set. Steel or timber set placed between existing sets to provide additional support.

Lagging. Steel plates or beams or wood planking placed above and on sides of steel ribs to contain broken rock and to prevent its fall into an underground opening. Also acts to receive and transfer rock loads to ribs, after appropriate blocking. Spacing depends on local conditions.

Left rib. The steel rib on the left side of the tunnel as one faces the tunnel heading.

Liner plate. Preformed plain or corrugated steel plates placed behind or between ribs as tight lagging to contain bad ground, to divert water flows, and to distribute rock loads evenly to ribs.

Muck. Disaggregated rock formed by blasting operation or by the free flow of incompetent material into an underground opening.

Mucking machine. The machine used to load broken rock for haulage out of underground excavations.

Overbreak. Rock removed from outside the payline as defined in the specifications. Usually expressed as the percentage of material removed in a cross-sectional area relative to the area within the payline. Also may be expressed as a volume percent.

Payline. The line beyond which the contractor shall not be paid for excavation. Excavation outside the payline is done at the contractor's expense.

Permanent support. The concrete lining of the tunnel. Steel and timber supports are regarded as temporary supports.

Popping rock. Stressed rock that fails with explosive violence and ejects large and small rock fragments at high velocity.

Pressure tunnel. A tunnel with control works at the outlet and designed to withstand, without loss or structural failure of the tunnel, water stored in the tunnel under hydrostatic head. In the Roberts Tunnel, with the outlet valves closed and Dillon Reservoir filled to capacity, the hydrostatic pressure in the tunnel near the surge-chamber shaft is equivalent to that of a standing column of water about 360 feet in height-that is, about 156 psi.
Progress. A measure of the speed and efficiency with which construction of any kind proceeds.

Progress report. In the Roberts Tunnel operation, progress was reported twice each month. The report periods extended from the first to the fifteenth and from the fifteenth to the last day of each month.

Raveling. Ground that breaks into small pieces when drilled and tends to cave or slough into tunnel.

Rib. A curved steel segment comprising half of a steel set or support.

Right rib. The steel rib on the right side of the tunnel as one faces the tunnel heading.

Roof. The upper part of a tunnel, especially that part of the tunnel immediately above the centerline.

Rock bolt. Steel bolt that is split at one end and inserted into drilled hole in rock to support the rock. Head of bolt is forced against a steel plate next to the rock to make bolting action more effective.

Running ground. Clayey or sandy aggregate, usually watersaturated, that flows freely into underground excavations.

Spalling rock. A rock mass under stress that yields thin slabs or wedges of rock by rapid failure. Slabs commonly form parallel to walls or to arch of an opening in rock.

Spiling. Pointed steel bars or rails, or wood planks or logs driven into the tunnel heading to support incompetent rock until supports can be placed. Usually, the spiling is driven above and beyond the supports nearest the heading, or on top of and beyond a false set.

Spitting rock. A rock mass under stress that breaks and ejects small fragments with considerable velocity.

Spreader. Wood plank or steel beam placed between ribs to maintain tension on tie rods or preserve alinement. Also called "collar brace."

Spring line. The line across or parallel to the tunnel, above which the steel ribs are bent to a radius of curvature different from that below it. Longest horizontal dimension between steel ribs. May or may not coincide with centerline.

Squeezing ground. Incompetent material, generally clayey, that behaves plastically under stress and tends to close the tunnel opening because of adjacent or superjacent loads.

Station. Distance from zero point measured in hundreds and fractions of feet. For example, station $105+06.5$ is $10,506.5$ feet from station $0+00$.

Steel rib. One of the segments of bent structural steel bolted to another rib to form a steel support or steel set in the tunnel.

Steel set. Steel support consisting of two ribs bolted or welded together. May include a strut across the invert of the tunnel.

Strut. Sometimes called "invert struts" are steel or timber seg. ments placed between steel ribs across tunnel invert to provide additional strength. Bolted, welded, or otherwise fastened to bottom extensions of ribs.

Support. Any fabricated structure, steel, wood, or concrete, placed to prevent failure of rocks around underground openings.

Swelling ground. Rock that swells after being exposed. Usually increases in volume because of hydration of clay minerals in an altered rock.

Temporary support. Support placed to support tunnel rocks until permanent supports can be installed. All supports except the concrete are generally regarded as temporary.

Tie rod. Steel rod threaded at both ends. Used as a connection between adjacent steel sets to hold sets in place and provide strength in the direction of the tunnel.

Timber lagging. Timber planks placed on sides and on top of steel or timber sets to contain exposed rocks between the sets and to transmit loads to the steel sets. 
Top heading. A small tunnel opening ahead of the full-size opening. Used to probe and place temporary supports in exceedingly incompetent or wet sections of tunnel.

Tunnel face. The tunnel heading.

Tunnel section. Outlines of tunnel as measured at right angles to centerline. Also, any portion of the tunnel measured parallel to the direction of the tunnel.

Tunnel supports. Wood, steel, or concrete structures placed to prevent collapse or failure of tunnel rocks.
Wall plate. Steel or timber beams of various designs placed longitudinally along sides of tunnel to act as a level support for ribs. Commonly, the wall plate serves to transmit loads from the ribs to blocks or posts with a spacing different from that of the ribs and distributes loads on ribs through the intervals between ribs.

Wedge. Wood wedge used to hold lagging or steel supports in place.

Working face. The heading being excavated by drilling and blasting. 


\title{
GEOLOGY OF THE EASTERN PART OF THE HAROLD D. ROBERTS TUNNEL, COLORADO (STATIONS 690+00 to 1238+58)
}

\author{
By LAWrence A. WARNER and CHARLES S. ROBINSON
}

\section{ABSTRACT}

During construction of the Roberts Tunnel, a wealth of geologic and engineering data was obtained. This report quantifies and correlates these data for the eastern part of the tunnel, which is almost entirely in rocks of Precambrian age.

The rock types intersected by the Roberts Tunnel between station $690+00$ and the East Portal (station 1238+58) comprise thick units of amphibolite, migmatite, microcline gneiss, and biotite gneiss, and schist-believed to be largely of metasedimentary origin. These units were invaded by granitic plutons, which resembled the Boulder Creek and Silver Plume Granites found in other parts of the Front Range. Both the metasedimentary units and the granitic plutons contain dikes and irregular lenses of pegmatite and aplite.

The metasedimentary rocks are well foliated and are complexly folded and faulted. A few broad asymmetrical folds are recognized that have wave lengths and amplitudes of a few to several miles. Numerous smaller folds are superimposed on these major folds. In general, the fold axes plunge about $50^{\circ}$ to the northwest. Major faults trend northeast and northwest and are associated with the Front Range mineral belt, which trends northeast across the route of the tunnel. These faults show no relationship to the rock fabric, whereas the more numerous minor faults tend to be parallel to foliation. The major faults are thought to have resulted largely from Laramide deformation. The North Fork fault zone, however, which parallels the southeast margin of the mineral belt, has a Precambrian ancestry.

Joints are prominent in all the rock types, but the directions and intensity of jointing change with locality. The joint patterns bear little or no relationship to fault patterns or to rock fabric, and the joints are thought to have formed mainly later than the faults.

Moderate to heavy waterflows were encountered where the tunnel penetrated permeable faults and fracture zones. At several places, high pressure grouting was required to seal the fractures. Particularly heavy flows, associated with fractured layers of microcline gneiss, were encountered in the vicinity of station $763+00$, necessitating installation of a concrete bulkhead to permit grouting of the fractured rock.

More than half the tunnel in Precambrian rock required steel supports in the form of horseshoe-shaped $H$ ribs spaced at 2- to 6-foot intervals. In addition, rock bolts were used to stabilize slabby rock, encountered mainly in biotite gneiss, particularly where the foliation forms a small angle with the tunnel axis. Gunite was employed intermittently to seal fractured rock and to prevent air slaking of altered rock.

Support requirements for the various rock types show a rough inverse proportion to average values of elastic constants for the rocks. In general, the more massive rocks required less support than the well foliated rocks. Because of its greater susceptibility to hydrothermal alteration, the Boulder Creek Granite required more support than the Silver Plume Granite. The need for support was also directly proportional to the incidence of faults. In contrast, well-jointed rocks generally required less support than poorly jointed rocks.

Overbreak studies were made for 21 selected tunnel intervals representing a variety of geological conditions. The studies show that the average overbreak is greater in supported than in unsupported rock. Overbreak was controlled partly by faults and joints and partly by the rock fabric. In the well-foliated rocks, the shape and diameter of the rock bore conformed most nearly to the desired shape where the foliation is approximately vertical and parallel to the tunnel axis.

\section{INTRODUCTION}

\section{THE SERIES}

The geology at tunnel level for the eastern part of the Harold D. Roberts Tunnel is described in this chapter. Chapters A, B, and C have already been published and cover the following subjects: Chapter A-History of geologic investigations, engineering design, and construction methods of the tunnel (Wahlstrom, 1974); Chapter B-General geology of the tunnel area (Robinson and others, 1974); Chapter C-Engineering geology of the western part of the tunnel (Wahlstrom and others, 1981). Chapter E, the final chapter of the series on the Roberts Tunnel, summarizes the engineering geology and gives a critical review and analysis of the application of geology during planning and construction of a major water tunnel (Wahlstrom, 1981).

The reader may find it of interest to compare the engineering geology of the western part of the tunnel (Chap. C) with the engineering geology of the eastern part. Chapter $\mathrm{C}$ consists of four sections that describe the geology of a different geologic province. The first section describes the engineering geology of the tunnel in Mesozoic sedimentary rocks west of the Williams Range thrust fault; the second section describes the engineering geology of the tunnel in the Precambrian rocks of the Williams Range thrust 
plate; the third section describes the engineering geology of the tunnel in the metamorphosed sedimentary rocks east of the Williams Range thrust fault; and the fourth section describes the engineering geology of the tunnel in the Tertiary Montezuma stock.

\section{HISTORY AND GENERAL GEOLOGY OF THE TUNNEL}

The Harold D. Roberts Tunnel was constructed to divert water from the Blue River near Dillon, Colo., on the western slope of the Continental Divide, to the North Fork of the South Platte River near Grant, Colo., on the eastern slope of the Continental Divide, a distance of 23.3 miles (fig. 1). This water is used for domestic and industrial purposes by the City and County of Denver.

The Roberts Tunnel transects a geologically complex area of the Front Range of the Colorado Rocky Mountains (fig. 2). The area consists of Precambrian igneous and metasedimentary rocks, Mesozoic sedimentary rocks, and Tertiary igneous rocks. A complex structural history includes folding and faulting during Precambrian time and the Laramide orogeny.

The Precambrian rocks, which comprise about two-thirds of the area penetrated by the tunnel, consist of a sequence of metasedimentary rocks that are invaded by igneous rocks. The Precambrian rocks occur in the eastern part of the tunnel and in the Williams Range thrust plate (fig. 2). The metasedimentary rocks consist of interlayered biotitequartz-plagioclase gneiss and schist, hornblendeplagioclase gneiss, biotite-quartz-microcline gneiss and schist, amphibolite, calc-silicate rocks, and quartzite. The igneous rocks include dikes and irregularly shaped plutons similar in mineral composition, structure, and relative age to the Boulder Creek Granite and the Silver Plume Granite. Pegmatite and aplite dikes, probably related to the Precambrian granitic rocks, occur locally throughout the area of Precambrian rocks. The Precambrian rocks of the Williams Range thrust plate have been extensively sheared and altered, and their prior characteristics are difficult to determine.

Sedimentary rocks of Mesozoic age are exposed along the western one-fourth of the tunnel (fig. 2). These are the Entrada(?) Sandstone and Morrison Formation of Late Jurassic age, the Dakota Group of Early Cretaceous age, the Benton Shale of Early and Late Cretaceous age, and the Niobrara Formation and Pierre Shale of Late Cretaceous age. Underlying sedimentary rocks (the Maroon Formation of Pennsylvanian and Permian age and the Lykins For- mation of Permian and Triassic(?) age) are exposed to the west of the tunnel and are intersected by drill holes along the tunnel line. The sedimentary rocks dip eastward toward the axis of the Front Range.

The Williams Range thrust fault, which superimposed Precambrian rocks on the Pierre Shale, developed early in the Laramide Revolution. Following this period of thrusting, the Montezuma Quartz Monzonite was emplaced. The tunnel transects about 4.5 miles of the Montezuma stock (fig. 2). As a result of the intrusion of the stock, the Williams Range thrust fault was folded upward, and the tunnel intersects the fault surface at two points. Between the eastern exposure of the thrust and the Montezuma stock is a sequence of shale and siltstone that are metamorphosed to hornfels in proximity to the stock. Most of this sequence of shale and siltstone is believed to be equivalent to part of the Pierre Shale to the west of the Williams Range thrust fault.

Preceding and following the intrusion of the Montezuma stock, a series of dikes were emplaced in the Precambrian units around the stock. The oldest of these dikes consist of augite or hornblende diorite. The dikes contemporaneous in age and younger than the stock are of latite and rhyolite porphyry.

The structural features of the Front Range were formed chiefly during Precambrian time and the Laramide orogeny. During Precambrian time, Precambrian sedimentary rocks were metamorphosed and plastically deformed, were intruded by igneous rocks, and were cataclastically deformed. The Laramide deformation resulted in the uplift of the Front Range, in the development of the Williams Range thrust fault, and in the formation of the Front Range mineral belt. The mineral belt is a northeast-trending zone of faults, veins (with associated alteration), and igneous intrusions, which extend diagonally across the range. The structural development of the mineral belt was in part controlled by the preexisting Precambrian structural features.

\section{GENERAL GEOLOGY FROM STATION 690+00 TO THE EAST PORTAL}

The Roberts Tunnel between station $690+00$ and the East Portal (sta. 1238+58) is chiefly in rocks of Precambrian age. One small dike of probable Tertiary age was encountered. The Precambrian rocks can be divided on the basis of their genesis into metasedimentary rocks and igneous rocks. The metasedimentary rocks can be divided into four units based on their mineral composition and fabric. They are an amphibolite unit, a migmatite unit, a microcline gneiss unit, and a biotite gneiss and schist unit. The igneous rocks include an older granite (Boulder 


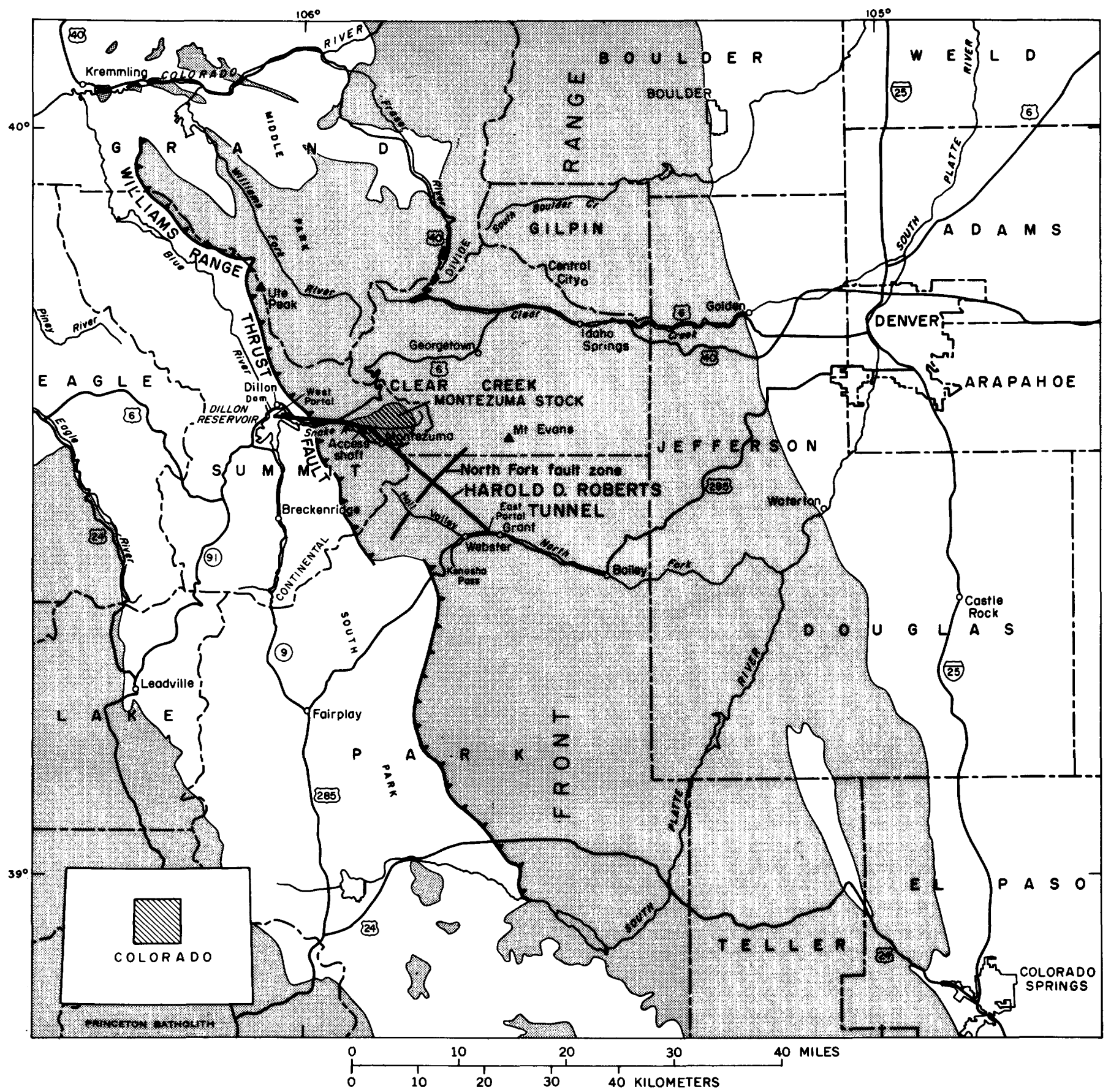

EXPLANATION

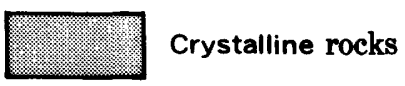

Sedimentary rocks

Figure 1.-Location of Harold D. Roberts Tunnel.

Creek Granite) and a younger granite (Silver Plume Granite). Throughout the tunnel are dikes of pegmatite and aplite, which are considered to be of Precambrian age.
The Precambrian rocks are generally well foliated and are complexly folded and faulted. Several large asymmetrical folds were recognized-with numerous minor folds superimposed. Major faults trend 


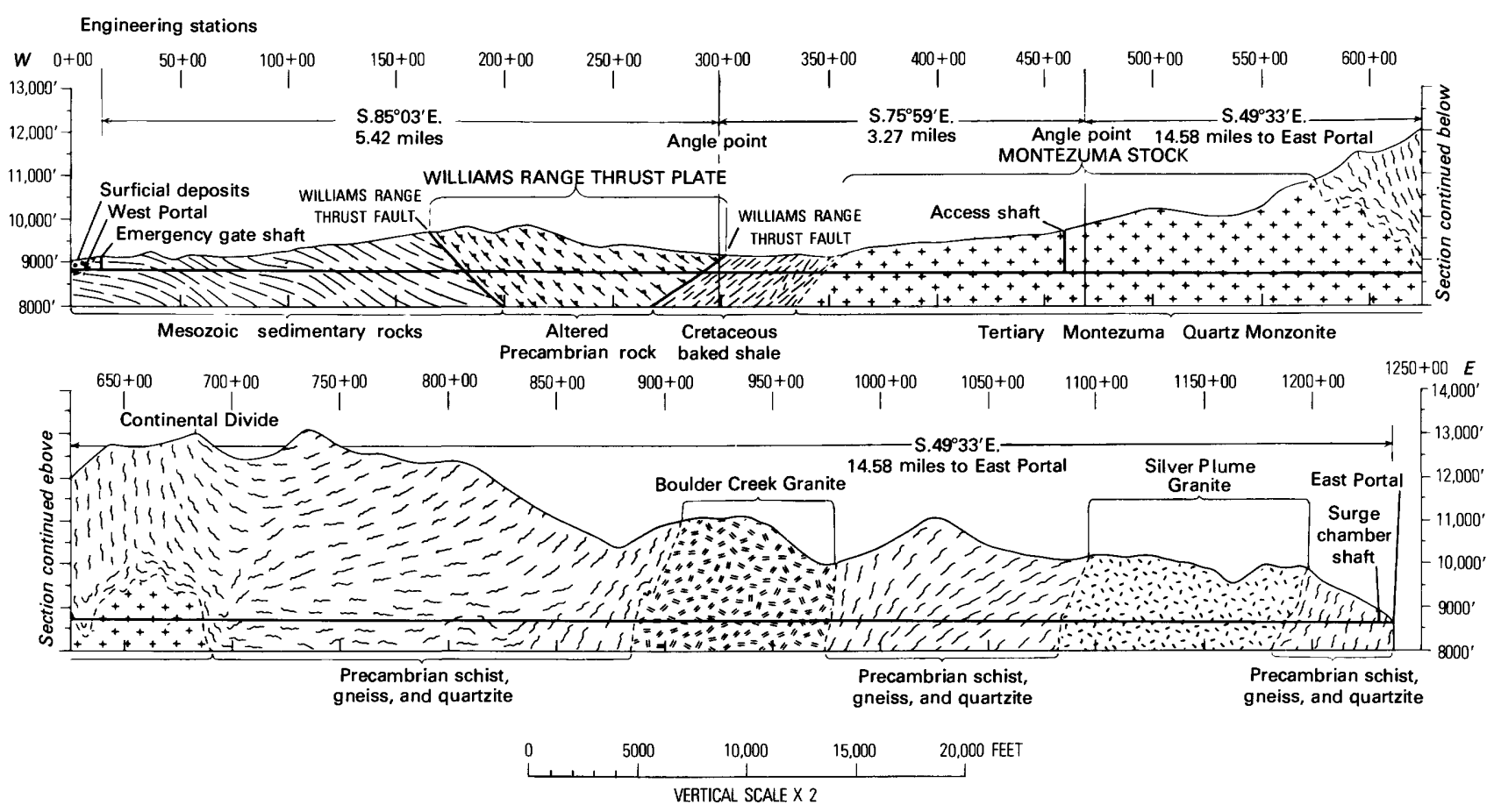

FigURE 2.-Generalized geologic section of the Harold D. Roberts Tunnel. Geology from maps prepared for Tipton and Kalmbach Inc. by E. E. Wahlstrom, L. A. Warner, and Quentin Hornback. Published with permission of the Board of Water Commissioners, City and County of Denver.

northeast and northwest and are associated with the Front Range mineral belt. Most of the faults recognized are believed to have resulted from Laramide deformation. One fault, however, the North Fork fault, is of Precambrian ancestry.

Joints are prominent in all rock types. The joint patterns have little relationship to the fault patterns or to rock fabric, and most are thought to have formed later than the faults.

The relation of the geology of this interval of the Roberts Tunnel to the regional geology of the Front Range is discussed in Chapter B. A discussion of the Precambrian geology, with a more detailed discussion of the genesis of Precambrian rock types has previously been published (Warner and Robinson, 1967).

\section{ROCK UNITS}

The rocks penetrated along the part of the tunnel discussed in this chapter are of Precambrian age, with the exception of small dikes and veins emplaced during the Laramide orogeny. The Precambrian rocks constitute the regional basement complex and consist of ancient metasedimentary units invaded by granitic plutons. The rock types are similar to those described from other parts of the central Front Range in reports by Lovering and Goddard (1950), Harrison and Wells $(1956,1959)$, and Moench, Harrison, and Sims (1962). Distribution of the rock units is shown on plate 1 .

\section{METASEDIMENTARY ROCKS}

The metamorphic rocks comprise a layered sequence of lithologic units composed of a variety of rock types-biotite gneiss and schist, microcline gneiss, migmatite, amphibolite, calc-silicate rock, quartzite, and marble. The mineral assemblages place the rocks in the sillimanite-almandine subfacies of the almandine-amphibolite facies of Fyfe, Turner, and Verhoogen (1958, p. 228-232), although agreement with the theoretical assemblages is only approximate. Premetamorphic equivalents are thought to have been pelitic, quartzofeldspathic, and calcareous rocks of sedimentary origin (Warner and Robinson, 1967, p. 94-95).

The sequence corresponds to what has been called the Idaho Springs Formation (Lovering and Goddard, 1950, p. 19), which, as noted by Wahlstrom and Kim (1959, p. 1219), does not constitute a formation in the usual sense of the term. The rocks may be 
divided into four mappable units, each of which might be given formational status. In this report the units are designated by lithologic terms, corresponding to the dominant rock type in each. Because of structural complications and the emplacement of igneous plutons, the thickness and stratigraphic sequence of the units are uncertain. A summary of the supposed relationships is given in the following table.

Lithologic succession of Precambrian metamorphic rocks along southeastern segment of Harold D. Roberts Tunnel

\begin{tabular}{|c|c|c|}
\hline $\begin{array}{c}\text { Unit } \\
\text { (In order of assumed } \\
\text { age, youngest at } \\
\text { top) }\end{array}$ & Lithology & $\begin{array}{c}\text { Estimated } \\
\text { minimum } \\
\text { thickness } \\
\text { (feet) }\end{array}$ \\
\hline $\begin{array}{l}\text { Biotite gneiss } \\
\text { and schist. }\end{array}$ & $\begin{array}{l}\text { Dominantly biotite-quartz- } \\
\text { plagioclase gneiss grading } \\
\text { into schist. Occasional } \\
\text { layers of biotite-microcline } \\
\text { gneiss in lower and middle } \\
\text { part and hornblende-plagi- } \\
\text { oclase gneiss in middle and } \\
\text { upper part. }\end{array}$ & 7,500 \\
\hline $\begin{array}{l}\text { Microcline } \\
\text { gneiss. }\end{array}$ & $\begin{array}{l}\text { Microcline-quartz-plagioclase- } \\
\text { biotite gneiss with composition } \\
\text { of quartz monzonite or granite. } \\
\text { Contains occasional layers of } \\
\text { biotite gneiss or schist. }\end{array}$ & 2,000 \\
\hline Migmatite .............. & $\begin{array}{l}\text { Microcline-quartz-plagioclase } \\
\text { and biotite-quartz-microcline } \\
\text { gneiss and schist intimately } \\
\text { mixed with granitic material, } \\
\text { mainly pegmatite and aplite. }\end{array}$ & 2,500 \\
\hline Amphibolite .......... & $\begin{array}{l}\text { Dominately hornblende-biotite- } \\
\text { plagioclase gneiss and calc- } \\
\text { silicate rock with occasional } \\
\text { layers or lenses of biotite } \\
\text { gneiss, quartzite, and } \\
\text { impure marble. }\end{array}$ & 3,000 \\
\hline
\end{tabular}

\section{AMPHIBOLITE}

Dark-green to black amphibolite and calc-silicate rock, in layers a few feet to several tens of feet thick, comprise what is believed to be the lowest stratigraphic unit. The unit appears to occupy the core of an asymmetrical anticline that has been invaded by Silver Plume Granite (pl. 1, stas. 1092+00 to $1229+00$ ). Large to small blocks of the amphibolite and associated rocks are contained in the granite and commonly are bordered by pegmatite casings about 2-10 feet thick. Rocks comprising this complex were first penetrated along the tunnel about 1,000 feet from the East Portal (pl. 1). The metamorphic rocks were so disturbed by the folding and faulting and by the emplacement of the granite that precise reconstruction of the unit is impossible. It is estimated to be at least 3,500 feet thick, and if structural interpretations are correct, the base is not exposed.

The dominant rock type is a hornblende-biotiteplagioclase gneiss that occurs in well to poorly foliated layers. Yellow-green pleochroic hornblende, partly altered to chlorite, in places constitutes more than 75 percent of the volume. The only other major constituents present in all analyzed samples are biotite and plagioclase $\left(A n_{31-47}\right)$. Quartz, microcline, pyroxene, and epidote are locally abundant; apatite and sphene are the principal accessory minerals. Modal compositions are given in the following table.

Modes (volume percent) of amphibolite

Leaders (......) indicate mineral not present; $\mathrm{Ca}$, calcite; Ep, epidote $\mathrm{Py}$, clinopyroxene; Ma, magnetite-ilmenite; Mu, muscovite; $\mathrm{Sp}$, sphene.

\begin{tabular}{|c|c|c|c|c|c|c|c|}
\hline $\begin{array}{l}\text { Sample } \\
\text { station }\end{array}$ & Quartz & Microcline & Plagioclase & Biotite & Hornblende & Other & $\begin{array}{l}\text { Acces- } \\
\text { sories }{ }^{1}\end{array}$ \\
\hline $2858+68$ & 13.5 & $\ldots \ldots \ldots . .$. & 47.3 & 21.6 & 12.4 & $\begin{array}{l}\mathrm{Ma}-3.0 \\
\mathrm{Ca}-1.4\end{array}$ & 0.8 \\
\hline${ }^{2} 1075+90$ & 5.6 & $\ldots \ldots \ldots . .$. & 12.1 & 15.1 & 64 & $\mathbf{M u}-\mathbf{1}$ & 2.2 \\
\hline $1107+85$ & Trace & $\ldots \ldots \ldots . .$. & 3.2 & 39.2 & 52.1 & $\begin{array}{l}\mathrm{Sp}-2.6 \\
\mathrm{Ap}-1.7\end{array}$ & 1.2 \\
\hline $1132+30$ & 3.2 & $\ldots \ldots \ldots . .$. & 11.9 & 1.6 & 76.8 & $\begin{array}{l}\mathrm{Ma}-2.1 \\
\mathrm{Ap}-1.5 \\
\mathrm{Ca}-1.2\end{array}$ & 1.7 \\
\hline $1161+20$ & 2.6 & 26.4 & 12.7 & 9.5 & 39.5 & $\begin{array}{l}\mathrm{Py}-6.8 \\
\mathrm{Sp}-1.5\end{array}$ & 1 \\
\hline $1181+62$ & 5.6 & 35.6 & 8 & 13.8 & 34.2 & $\mathrm{Sp}-2.2$ & .6 \\
\hline $1190+00$ & .......... & 38.6 & 15.2 & 36 & 2.2 & $\begin{array}{l}\mathrm{Ep}-4 \\
\mathrm{Ma}-1.6 \\
\mathrm{Py}-1.2\end{array}$ & 1.2 \\
\hline $1196+50$ & 18.6 & $\ldots$ & 30 & 17.2 & 20.6 & $\begin{array}{l}\mathrm{Ma}-6.4 \\
\mathrm{Ap}-5.2\end{array}$ & 2 \\
\hline $1220+75$ & 12.6 & $\ldots \ldots \ldots$ & 41.6 & 15.2 & 20.6 & $\begin{array}{l}\mathrm{Ap}-6 \\
\mathrm{Ma}-3.2\end{array}$ & .8 \\
\hline${ }^{2} 1234+72$ & 18.1 & $\ldots .$. & 38.1 & 13.2 & 17.1 & $\begin{array}{l}\mathrm{Ep}-6.6 \\
\mathrm{Ap}-1.8 \\
\mathrm{Sp}-1.5\end{array}$ & 3.6 \\
\hline Average & 8 & 10.1 & 22 & 18.2 & 33.9 & 6.3 & 1.5 \\
\hline
\end{tabular}

Includes minerals listed under "Others" plus zircon and pyrite. ${ }^{2}$ From small lenses.

In places, the unit consists mainly of massive to banded calc-silicate layers, which contain as much as 70 percent of a clinopyroxene-probably diopside. Garnet (grossularite-andradite), epidote, and am- 
phibole (hornblende or tremolite) are locally abundant; quartz and feldspar are generally scarce. Calcite is present in most of the samples studied and in places constitutes small lenses of impure marble. Scapolite was noted in some of the more calcareous rocks. Layers, which contain $85-90$ percent quartz, are commonly associated with the calc-silicate members; and biotite-rich layers of gneiss, schist, and migmatite occur sparingly.

\section{MIGMATITE}

From the East Portal to beyond station 1200+00 (pl. 1 ), the tunnel penetrated mainly schistose rocks, rich in biotite, containing numerous thin layers and lenses of granitic material and in places thick sills or dikes of pegmatite and aplite. Although the rock grades locally into biotite schist or gneiss containing little or no granitic material, it was impractical to isolate layers of such rocks, and the entire schistose assemblage was mapped as migmatite. A few conspicuous layers of amphibolite are present in the sequence. A similar lithologic assemblage was encountered northwest of station $1083+00$ (pl. 1).

Underground data suggest the possibility of two migmatite units, one above and the other below the amphibolite unit. Surface mapping (Chap. B, pl. 1), however, indicates a single migmatite unit repeated by anticlinal folding, with amphibolite in the core and migmatite on the flanks of the fold. On the basis of this structure, the migmatite is interpreted to be stratigraphically younger than the amphibolite and older than the microcline gneiss, which structurally overlies it. In places the migmatite is much contorted by minor convolute folds, suggesting that in deformation it behaved as an incompetent unit between the relatively more competent rocks above and below it. The thickness of the migmatite is estimated from structural data to be at least 2,500 feet.

\section{MICROCLINE GNEISS}

Between about stations $977+00$ and $1011+00$ (pl. 1), the rock consists largely of a microcline-quartzplagioclase-biotite gneiss. Several layers of biotite gneiss and schist are present, some as much as 100 feet thick. The unit terminates to the northwest against a pluton of Boulder Creek Granite, and the top of the microcline gneiss unit is not exposed. The thickness of the microcline gneiss penetrated by the tunnel east of the Boulder Creek pluton is estimated to be about 2,000 feet. Three layers of microcline gneiss, each about 100 to 200 feet thick, were also penetrated by the tunnel near stations $730+00$, $760+00$, and $818+00$ (pl. 1).

A typical sample of the gneiss is medium grained, has granitoid texture, and contains about equal parts of quartz, microcline, and plagioclase $\left(A n_{25}\right)$. Biotite and muscovite-in amounts less than the biotite-amount to about 10 percent of the volume. The main accessory minerals are apatite, zircon, and sphene. Modes of selected samples are given in the following table. The average mode is similar to that of the granitic plutons in the area.

Modes (volume percent) of microcline gneiss

\begin{tabular}{ccccccc}
\hline $\begin{array}{c}\text { Sample } \\
\text { station }\end{array}$ & Quartz & Microcline Plagioclase & Biotite & Muscovite & $\begin{array}{c}\text { Acces- } \\
\text { sories }\end{array}$ \\
\hline $756+00$ & 36.0 & 31.1 & 24.0 & 6.1 & 2.2 & 0.6 \\
$764+50$ & 34.4 & 23.5 & 30.4 & 57.2 & 1.8 & 2.7 \\
$818+00$ & 24.5 & 15.9 & 35.3 & 13.6 & 7.4 & 3.3 \\
$2884+15$ & 34 & 33.2 & 24 & 5 & 2.2 & 1.6 \\
$912+00$ & 27.7 & 30.3 & 31.6 & 7.9 & 1.1 & 1.4 \\
$993+10$ & 30.9 & 31.3 & 28.4 & 7.3 & .8 & 1.3 \\
$1004+95$ & 34 & 30 & 27.1 & 6.2 & 1.2 & 1.5 \\
Average & 31.6 & 27.9 & 28.7 & 7.6 & 2.4 & 1.8 \\
\hline
\end{tabular}

${ }^{1}$ Apatite, zircon, sphene, and opaque minerals.

${ }^{2}$ Thin layer in biotite gneiss and schist not shown on plate 1.

BIOTITE GNEISS AND SCHIST

Between station $886+00$, at the west margin of the Boulder Creek pluton, and station $690+00$, at the southern boundary of the Montezuma stock, the tunnel is mainly a biotite-quartz-plagioclase gneiss and schist (pl. 1). This sequence is repeated by anticlinal folding. Two layers consisting mainly of microcline gneiss, each about 200 feet thick, occur at tunnel level on the west flank of the fold. The lower one is repeated on the east flank of the fold; the upper one apparently pinches out. A layer about 800 feet thick, consisting mainly of amphibolite, was penetrated by the tunnel on the east flank of the fold $(\approx$ sta. $856+00)$, and two thinner layers, at about the same stratigraphic position, are exposed on the west flank at the surface (stas. $762+50$ and $780+50$ ).

The biotite gneiss and schist is a fine-grained closely foliated rock with gneissoid to schistose structure. Distinguishing gneiss from schist proved impractical in the mapping. The average specimen contains about a third quartz, somewhat less plagioclase $\left(\mathrm{An}_{18-33}\right)$, and much less microcline. Biotite and muscovite commonly account for more than 20 percent of the volume, the former being the more abundant. Some layers contain late irregular flakes of muscovite with randon orientation, in places several millimeters in diameter. Sillimanite is commonly present in small amounts and locally exceeds 10 percent. The main accessory minerals are apatite, zircon, and sphene. Modes of selected samples from all the lithologic units are given in the following table. 
Modes (volume percent) of biotite gneiss and schist

[Leaders (.........) indicate mineral not present]

\begin{tabular}{|c|c|c|c|c|c|c|c|}
\hline $\begin{array}{l}\text { Sample } \\
\text { station }\end{array}$ & Quartz & K-feldspar ${ }^{1}$ & Plagioclase & Biotite & Muscovite & Other $^{2}$ & $\begin{array}{l}\text { Acces- } \\
\text { sories }\end{array}$ \\
\hline $700+90$ & 39.8 & 2.4 & 37 & 2.8 & 15.7 & 1.2 & 1.4 \\
\hline $707+00$ & 18.6 & $\ldots \ldots$ & 21.8 & 51.6 & $\ldots \ldots \ldots$ & 6.4 & 1.6 \\
\hline $723+00$ & 1.3 & 44.6 & 37.5 & 11.8 & 2.6 & $\ldots \ldots \ldots . .$. & 2.2 \\
\hline $727+70$ & 41.8 & 12 & 31.6 & 12.8 & 1 & .4 & .4 \\
\hline $731+95$ & 40 & 28.8 & 24.4 & 5 & 1.6 & .................. & .2 \\
\hline $744+55$ & 33.3 & ................ & 34.3 & 19.1 & 5.6 & 7.2 & .5 \\
\hline $777+55$ & 14.4 & 6.2 & 50.6 & 24.8 & 2.6 & .................. & 1.4 \\
\hline $781+95$ & 36.8 & ................ & 45.8 & 17.2 & $\ldots \ldots . . .$. & ........... & .2 \\
\hline $781+95$ & 24 & 28.6 & 29.2 & 17.8 & ................. & $\ldots \ldots \ldots . .$. & .4 \\
\hline $788+00$ & 46.8 & $\ldots \ldots \ldots .$. & 42 & 10.6 & ................ & $\ldots \ldots \ldots$ & .6 \\
\hline $810+40$ & 45.7 & 6.1 & 16.4 & 17.6 & 8.4 & 4.3 & 1.5 \\
\hline $829+40$ & 34.4 & 6.5 & 13.6 & 31.4 & 5.6 & 5.2 & 3.2 \\
\hline $847+57$ & 41.1 & 23.1 & 19.9 & 14 & 1.4 & $\ldots \ldots \ldots .$. & .5 \\
\hline $849+05$ & 57 & ............ & 28.2 & 13.1 & 1.2 & $\ldots \ldots \ldots$ & .5 \\
\hline $872+07$ & 45.8 & 1.5 & 2.6 & 28.6 & 6.7 & 12.7 & 2 \\
\hline $875+65$ & 28.2 & 9.6 & 36.4 & 22.8 & 2 & $\ldots \ldots \ldots . . .$. & 1 \\
\hline $885+75$ & 20.4 & 35.4 & 20.2 & 20.4 & 1.8 & ................. & 1.8 \\
\hline $915+05$ & 44.8 & 4.6 & 3.2 & 37.6 & 3.8 & 3.6 & \\
\hline $930+50$ & 54.2 & …….... & 36.2 & 8.4 & ............ & $\ldots \ldots \ldots . .$. & 1.2 \\
\hline${ }^{4} 1017+50$ & 37.4 & $\ldots+\cdots . .$. & 33.5 & 26.8 & ............... & $\ldots \ldots \ldots$ & 2.3 \\
\hline$+1039+50$ & 50.4 & 1 & 34.8 & 11 & .4 & ............... & 2.4 \\
\hline${ }^{4} 1043+10$ & 39.3 & 28.4 & 14.9 & 12.2 & 1.9 & ................ & 3.3 \\
\hline${ }^{4} 1063+25$ & 33.2 & 25.6 & 20.6 & 18.2 & 1.4 & ............... & 1 \\
\hline${ }^{4} 1080+70$ & 42.3 & $\ldots \ldots . . .$. & 42.9 & 13.2 & .6 & ............. & .5 \\
\hline $1200+40$ & 35.7 & 23.6 & .6 & 34.1 & 5.3 & $\ldots+. . . . . .$. & .7 \\
\hline${ }^{4} 1206+94$ & 47.2 & ............ & 34.6 & 17.2 & .6 & ............ & .5 \\
\hline${ }^{4} 1232+95$ & 29 & 9.1 & 5 & 39 & 4.8 & 12.7 & .4 \\
\hline Average & 36.65 & 10.82 & 27.00 & 19.61 & 2.70 & 1.92 & 1.30 \\
\hline
\end{tabular}

'Orthoclase in samples from stations $635+18$ through $727+70$; microcline in all other samples.

${ }^{2}$ Anhydrite (probably secondary) in sample from station $707+00$; sillimanite in all other samples.

${ }^{3}$ Include apatite, zircon, sphene, magnetite-ilmenite, and pyrite.

${ }^{4}$ Biotite gneiss and schist in migmatite unit.

Intrusion by the Boulder Creek Granite has obscured the relationship of the biotite gneiss and schist unit to the other rock units. Neither the base nor the top of the unit is exposed in the vicinity of the tunnel. Gross structural relationships, based largely on surface mapping, suggest that the unit is stratigraphically younger than the microcline gneiss. The exposed thickness of the unit is estimated to be about 7,500 feet.

\section{IGNEOUS ROCKS}

Precambrian granitic plutons have invaded the metasedimentary rocks along the route of the Roberts Tunnel, mainly between station $886+00$ and the East Portal (sta. 1238+58). These plutons resemble mineralogically, structurally, and in relative age the Boulder Creek and Silver Plume Granites described from various localities in the Front Range (Lovering and Goddard, 1950, p. 25-29).

Field relationships, together with petrographic and petrologic considerations, suggest that the granitic bodies penetrated in the tunnel were derived from magma that was formed below the level of the present terrain (Warner and Robinson, 1967, p. 98). They are regarded as mesozonal plutons in the sense defined by Buddington $(1959$, p. 676$)$.

Dikes and irregular bodies of Precambrian pegmatite and aplite are associated with the granitic plutons and are common in all the metamorphic units. Laramide age porphyry dikes, generally numerous along the southeast margin of the mineral belt, are sparse in this area. A few dikes of rhyolite and andesite were noted on the surface southeast of the Montezuma stock. The only dike of presumed Laramide age encountered at tunnel level was a 30 -foot thick dike of augite diorite at station $722+75$.

\section{BOULDER CREEK GRANITE}

Between stations $886+00$ and $977+00$, the tunnel passes through a granitic pluton of the Boulder Creek Granite (pl. 1). The rock is coarse grained and hypidiomorphic granular, with a crude foliation caused by alinement of biotite. The color is gray or gray-pink, the darker shades of which contain less microcline. The major constituents in the average sample are quartz, perthitic microcline, and plagioglase (oligoclase or sodic andesine) in about equal proportions. The plagioclase is commonly corroded and faintly zoned; the cores show alteration to sericite, but the borders are generally clear. Nearly equant grains of microcline, as much as $3 / 4$ inch in diameter, poikilitically include earlier grains of quartz and plagioclase. Biotite accounts for about 5 percent of the volume and muscovite for about 1 percent. Apatite, zircon, allanite, and magnetite are the chief accessory minerals; rutile needles are common in some of the biotite. Modes of selected samples of the granite are given in the following table.

Modes (volume percent) of Boulder Creek Granite

\begin{tabular}{ccccccc}
\hline $\begin{array}{l}\text { Sample } \\
\text { station }\end{array}$ & Quartz & Microcline & Plagioclase & Biotite & Muscovite & $\begin{array}{c}\text { Acces- } \\
\text { sories }\end{array}$ \\
\hline $886+18$ & 31.2 & 28.7 & 38.9 & 0.3 & 0.9 & 0.1 \\
$890+00$ & 21.1 & 46 & 27.6 & 3.4 & 1.4 & .5 \\
$897+50$ & 43.8 & 25.3 & 23.8 & 5.2 & .2 & 1.6 \\
$900+50$ & 45 & 26.2 & 23.4 & 3 & .3 & .6 \\
$905+35$ & 24.1 & 45.6 & 24.7 & 3 & .8 & 1.8 \\
$913+75$ & 31.8 & 27.1 & 26.7 & 9.3 & 3.2 & 1.8 \\
$928+30$ & 25.9 & 32.2 & 30.7 & 7.6 & .8 & 2.8 \\
$948+55$ & 23.2 & 34.7 & 32.9 & 8.3 & .1 & .9 \\
$955+90$ & 33.4 & 21.1 & 28.6 & 11.4 & 1.8 & 3.6 \\
$971+80$ & 26.6 & 32.6 & 35.2 & 4.5 & .2 & .9 \\
Average & 30.61 & 31.95 & 29.25 & 5.75 & .97 & 1.46 \\
\hline
\end{tabular}

${ }^{1}$ Apatite, zircon, allanite, sphene, monazite, and opaque minerals.

Surface mapping indicates that the major axis of the pluton is alined roughly, with the strike of foliation in the enclosing metamorphic rocks, but the 
contacts are locally discordant (Chap. B, pl. 1). At the surface the pluton is separated into two segments by a thick septum of biotite gneiss. The segments apparently converge downward, and at tunnel level the septum appears to be represented by a zone of large tabular inclusions. The two segments of the pluton differ slightly in modal composition, although the rocks are not readily distinguished in hand specimen. The major difference is in the plagioclase, which averages about $A_{25}$ in the eastern segment of the pluton and about $A n_{16}$ in the western segment.

\section{SILVER PLUME GRANITE}

Rocks resembling Silver Plume Granite occur in masses ranging in size and shape from small dikes and lenses to large stocklike plutons with irregular outlines. A typical specimen contains quartz, perthitic microcline, and sodic oligoclase $\left(\mathrm{An}_{14}\right)$ in about equal amounts, the three minerals accounting for about 90 percent of the volume. The remaining volume consists of mainly biotite with some muscovite and a few accessory minerals-chiefly apatite, zircon, and magnetite. Selected modes are shown in the following table.

Modes (volume percent) of Silver Plume Granite

\begin{tabular}{rlllllc}
\hline $\begin{array}{c}\text { Sample } \\
\text { station }\end{array}$ & Quartz & K-feldspar & Plagioclase & Biotite & Muscovite & $\begin{array}{c}\text { Acces- } \\
\text { sories }^{2}\end{array}$ \\
\hline $718+00$ & 39.0 & 29.4 & 25.7 & 3.6 & 1.8 & 0.4 \\
$908+50$ & 39.1 & 37.6 & 19.6 & 1.8 & 1.7 & .3 \\
$940+50$ & 27 & 38.5 & 27.5 & 2.7 & 3.3 & 1 \\
$956+40$ & 30.5 & 40.7 & 24.4 & 3.3 &..... & 1.1 \\
${ }^{1037+50}$ & 29.3 & 35.3 & 29.3 & 3.4 & 1.7 & 1 \\
$1068+50$ & 36.8 & 30.5 & 27.9 & .3 & 4 & .5 \\
$31085+50$ & 29.2 & 29 & 35.5 & 5.5 & .8 & .1 \\
$1111+00$ & 30.2 & 30.7 & 33.9 & 3.7 & .4 & 1.1 \\
$1129+10$ & 34.4 & 30.8 & 29.5 & 4.5 & .3 & .5 \\
$1138+40$ & 36.4 & 20.1 & 41.7 & 1.2 & .5 & .1 \\
$1147+00$ & 26.2 & 45.9 & 23.1 & 3.9 & .7 & .1 \\
$1155+30$ & 31.6 & 28.1 & 36.6 & 2.4 & .5 & .8 \\
$1158+00$ & 34 & 28.6 & 37 & .2 & .1 & .1 \\
$1166+00$ & 39.2 & 35.3 & 23.2 & 1.6 & .5 & .2 \\
$1186+72$ & 33.3 & 31.9 & 29.6 & 3.5 & 1.2 & .4 \\
$1218+59$ & 28.7 & 37.8 & 27.4 & 2.3 & 3.1 & .7 \\
Average & 32.81 & 33.14 & 29.49 & 2.74 & 1.29 & .53 \\
\hline
\end{tabular}

${ }^{1}$ Orthoclase in sample from station $718+00$; microcline in all others. ${ }^{2}$ Apatite, zircon, sphene, monazite, allanite, and opaque minerals.

${ }^{3}$ Silver Plume Granite in migmatite unit.

The rock is generally gray pink, medium grained, and hypidiomorphic granular. Commonly it shows a subporphyritic texture, which is due to relatively large lath-shaped Carlsbad twins of microcline. In the larger bodies, the feldspar laths generally are alined which produces a crude foliation; the smaller bodies tend to be massive.

As with the Boulder Creek Granite, the plutons of Silver Plume Granite are grossly alined with the foliation in the enclosing rock, but the contacts are more discordant, and there is a greater tendency toward formation of dikes and apophyses. Small bodies occur intermittently along the tunnel from East Portal to the contact of the Montezuma stock (sta. 690+00). The major bodies encountered at tunnel level are in the interval between stations $1083+00$ and $1201+50$ (pl. 1). Apparently, these are apophyses of the Kenosha batholith, which occupies a large area to the south in the vicinity of Kenosha Pass (Hutchinson, 1959; Trimble, 1960). The bodies occur along the trend of the amphibolite unit; large to small blocks and lenses of amphibolite account for roughly half of the rock observed in this interval of the tunnel. Irregular dikes of the granite commonly transect the larger blocks of amphibolite. The amphibolite unit appears to have been grossly brecciated and the granite to have been emplaced as a matrix.

Dikes of Silver Plume Granite occur in the Boulder Creek pluton. Some of these grade into pegmatite or aplite at the margins, a tendency noted also in the Silver Plume dikes in amphibolite.

\section{PEgMATITE AND APLITE}

Dikes, lenses, and irregular masses of pegmatite, which range in width from an inch to a few hundred feet, are abundant in the metamorphic rocks, particularly in the biotite gneiss and migmatite units. Similar bodies occur more sparingly in the granitic plutons. The pegmatite commonly grades into aplite, and some bodies consist mainly of aplite.

The average modal composition of the pegmatiteaplite, shown in the following table, is similar to those for the granites. Quartz, perthitic microcline, and plagioclase $\left(\mathrm{An}_{11}\right)$ are the dominant minerals.

Modes (volume percent) of pegmatite and aplite

\begin{tabular}{|c|c|c|c|c|c|c|c|}
\hline $\begin{array}{l}\text { Sample } \\
\text { station }\end{array}$ & Quartz & Microcline & Plagioclase & Biotite & Muscovite & $\begin{array}{l}\text { Acces- } \\
\text { sories }^{1}\end{array}$ & Rock type \\
\hline $750+90$ & 17.7 & 49.7 & 31.0 & 0.4 & 0.7 & 0.5 & Pegmatite \\
\hline $771+57$ & 34 & 14 & 49.1 & 1.5 & 1.3 & .1 & Do. \\
\hline $780+50$ & 29.3 & 49.6 & 16.8 & .1 & 4.2 & .1 & Do. \\
\hline $838+75$ & 31.6 & 37.3 & 26.7 & 2.3 & 1.8 & .3 & Aplite \\
\hline $852+50$ & 26.6 & 54.4 & 15.7 & .1 & 2.1 & 1.1 & Pegmatite \\
\hline $861+00$ & 29.2 & 36.7 & 33 & $\ldots \ldots \ldots$. & 1 & .1 & Do. \\
\hline $2872+72$ & 33.6 & 31.8 & 32.3 & .7 & 1.1 & .5 & Aplite \\
\hline $4876+80$ & 29.5 & 32.9 & 33.8 & 2.8 & .5 & .6 & Do. \\
\hline $882+60$ & 34.5 & 42.1 & 23.3 & $\ldots \ldots \ldots$. & $\ldots$ & .1 & Pegmatite \\
\hline $2949+57$ & 27 & 56.6 & 10.2 & 2.5 & 1.7 & 2 & Do. \\
\hline $2962+05$ & 30.7 & 39 & 25.1 & 3 & .7 & 1.5 & Aplite \\
\hline${ }^{2} 1068+50$ & 34 & 31.8 & 27.5 & .1 & 4.6 & 2 & Pegmatite \\
\hline${ }^{2} 1084+00$ & 8.1 & 47.5 & 41.9 & $\ldots \ldots \ldots$ & .6 & 1.9 & Do. \\
\hline $1118+25$ & 42.5 & ............. & 55.5 & $\ldots \ldots \ldots$ & .3 & 1.7 & Do. \\
\hline Average & 29.16 & 37.38 & 30.14 & .96 & 1.47 & .89 & \\
\hline
\end{tabular}

1Mainly zircon and apatite plus opaque minerals.

2Small pegmatite or aplite dikes in other rock units. Not shown on plate 1. 
Some pegmatites consist mainly of plagioclase, some of quartz, and some of microcline perthite. The aplites (and the pegmatite associated with them) are more uniform and commonly contain the three minerals in about equal amounts. Muscovite is generally more abundant than biotite, the total mica amounting to a few percent of the volume. The main accessory minerals are apatite and zircon.

The pegmatite associated with the metasedimentary rocks is not markedly different from that contained in the granites. Pegmatite is somewhat more abundant in the Silver Plume pluton than in the Boulder Creek pluton, but structural and petrographic data do not serve to distinguish the two occurrences. Criteria are lacking to classify the pegmatites according to episodes of granite emplacement, as done by Boos (1954) for pegmatites of the Denver Mountain Parks region. Pegmatite in Silver Plume Granite, however, may be inferred to have no relation to Boulder Creek Granite, because the latter is older.

In the interval between stations $1120+00$ and $1170+00$, small to large blocks of amphibolite in Silver Plume Granite are surrounded by pegmatite casings about 1-10 feet thick. The contacts of the pegmatite with the amphibolite are sharp; whereas, those with granite are gradational. Field relationships and petrologic considerations suggest that the pegmatite casings were formed by replacement of Silver Plume Granite (Warner and Robinson, 1967, p. 99-100). Reduced pressures are thought to have developed around the amphibolite inclusions during consolidation of the granite; this occurrence could have favored concentration of aqueous residual fluids at the inclusion boundaries. Such fluids could have caused recrystallization of granite to form pegmatite.

\section{AUGITE DIORITE}

A dike of augite diorite about 30 feet thick was encountered in the Roberts Tunnel at station $772+75$. Similar dikes were noted at the surface in a northwest-trending zone, which extends from the southern end of the North Fork fault, as mapped, to north of the access shaft west of Porcupine Peak (Chap. B, pl. 1).

The dike underground was dark gray to black, very fine grained, and slightly porphyritic. It was originally mapped as basalt. The phenocrysts are laths of plagioclase feldspar and subhedral crystals of augite, with maximum dimensions of about 0.08 in.

Microscopic examination showed that the rock consists of almost equal proportions of plagioclase and ferromagnesium minerals and 5-10 percent magnetite. The plagioclase is anhedral to subhedral, zoned, twinned, and altered, at least in part, to sericite. The composition of the plagioclase ranges from about $A n_{40}-A n_{50}$, the more calcic plagioclase forming the cores of the zoned plagioclase phenocrysts. The ferromagnesium minerals are augite and hornblende. Augite is the more abundant ferromagnesium mineral, and what hornblende (uralite) is present is apparently the product of the alteration of the augite. Magnetite, both as a primary mineral and as an alteration product of the augite and hornblende, constitutes 5-10 percent of the rock. Scattered anhedral grains of quartz constitute less than 1 percent of the rock. Anhedral to subhedral apatite occurs in trace amounts.

The name of augite diorite for dikes of this composition was introduced by Lovering and Goddard (1950, p. 44-50). They considered dikes of this compositton to be of Tertiary age, and to be among the oldest of the Tertiary dikes in the Front Range.

\section{STRUCTURE}

The region traversed by the Roberts Tunnel is at the junction of two major Laramide structural features, the Williams Range thrust fault and the Colorado mineral belt. The thrust fault defines the west margin of the Front Range and is a zone along which basement rocks have moved westward a few thousand feet to several miles over Mesozoic strata (Chap. C, p. C24). The Colorado mineral belt is a northeast-trending zone of faults and veins that extends diagonally across the central part of the Front Range (Chap. C, p. C51). It follows a zone of weakness defined by Precambrian shearing (Tweto and Sims, 1963). Faults, fracture patterns, and hydrothermal alteration associated with the mineral belt profoundly influenced advancement of the tunnel throughout most of its extent.

The Laramide fracture systems and related mineralization are superimposed on basement structural features, which were formed mainly by folding and shearing associated with deep-seated plutonism and metamorphism. The outcrop pattern of the layered Precambrian rocks in the tunnel area appears to outline a complexly folded asymmetrical synclinorium, which has an axial trace trending north to northeast (pl. 1). Folds and related linear elements within the complex plunge northward or westward at moderate to steep angles.

The synclinorium is bisected approximately along its axial trace by the North Fork fault, described by Wahlstrom and Kim (1959, p. 1234) as of Precambrian origin. Displacement on the fault is probably large, although the amount and direction of slip are unknown. None of the stratigraphic units can be 
correlated across the fault, and the Precambrian structural features on the two sides differ in orientation.

\section{FOLDS}

The megascopic fold pattern in the metamorphic complex is shown in cross section on plate 1 . Although the section is oblique to the fold axes, a series of large anticlines and synclines is indicated; these anticlines and synclines have wave lengths and amplitudes of as much as several miles (pl. 1). Axial planes of the folds trend north and dip to the west.

An anticline that involves the biotite gneiss unit is indicated in the interval between the Montezuma stock and the Boulder Creek pluton (pl. 1). The anticline is outlined in the tunnel by two layers of microcline gneiss. The westerly limb strikes northwest and shows moderate dips to the southwest. The easterly limb strikes northeast and is overturned to the northwest; it is broken by numerous faults apparently related to Laramide movement on the North Fork fault zone. Structural data obtained at tunnel level indicate that the axis of the fold, though probably irregular in attitude, plunges about $50^{\circ}$ to the west-northwest.

A similar anticlinal structure is suggested in the interval between the Boulder Creek pluton and the East Portal (pl. 1). The migmatite unit at the East Portal is surmised from surface mapping to be overturned to the northwest. It is thought to correlate by anticlinal folding with the migmatite west of the Silver Plume Granite-amplibolite complex, which is assumed to occupy the core of the anticline. The Boulder Creek pluton is thought to occupy a related syncline to the west, partly obliterated by movement on the North Fork fault zone. Structural data indicate that the attitudes of fold axes are highly irregular and suggest that the initial folds were disturbed by emplacement of the granitic plutons. An average axial plunge of about $50^{\circ}$ to the north-northwest is inferred.

\section{FOLIATION AND LINEATION}

The Precambrian rocks are well to poorly foliated, owing mainly to preferred orientation of biotite. The rocks rich in biotite show platy aggregates of quartz and feldspar closely interlayered with biotite, producing a schistose structure. Feldspathic units poor in biotite show only a crude alinement of minerals. Biotite and tabular hornblende account for the foliation in amphibolite layers. The foliation is dominantly parallel to bedding, which is defined by megascopic or microscopic alteration of lithologically different layers. No prominent $s$ planes that were clearly oblique to bedding were observed.
Equal-area plots of foliation poles were contoured for each rock unit or group of related units (pl. 1, area plots $C, F, I, K, M, P$.). Most of the contour diagrams show well to poorly defined girdles or partial girdles, the axes of which correspond to the mean of the axes of folding. The maxima and submaxima defined by the contours correspond to the dominant attitudes of foliation planes in the pertinent units.

Lineation, due mainly to alinement of mineral grains or clots in the plane of foliation, is locally conspicuous in the biotite gneiss and amphibolite units and is poorly defined in the granitic rocks. Hornblende prisms and elongate aggregates of biotite or quartz are the principal linear elements. Some of the biotite-rich layers show minute poorly defined crenulations, which are alined parallel to the mineral growth. These crenulations suggest the presence of an $s$ plane oblique to foliation (Cloos, 1946, p. 18-20), but none was observed in sawed specimens or thin sections. Small drag folds, common in schistose and migmatitic layers, show poor axial alinement but have an average orientation roughly parallel to that of the other linear elements (Chap. B, p. B28).

\section{FAULTS}

Faults are poorly exposed at the surface but were encountered at frequent intervals underground. The widths of the zones of movement range from less than 1 inch to more than 50 feet. Slip surfaces commonly are accompanied by a fraction of an inch to more than a foot of gouge. In general, the intensity of faulting increases northwestward along the southeastern segment of the tunnel The number of faults containing vein material, as well as the intensity of hydrothermal alteration, also increases in this direction. Only the major faults are shown on plates 1 and 2. It has been possible to connect a few faults at the surface with their counterparts at tunnel level, but most of the projections are conjectural.

The North Fork fault is not exposed on the surface above the Roberts Tunnel; however, its trace is visible on aerial photographs and is indicated by displacements of the rock units (Chap. B, p. B34). The flaser gneisses, breccia, and mylonite that characterize the fault zone in Hall Valley, a few miles southwest of the tunnel (Wahlstrom and Kim, 1959, p. 1235), were not encountered in the tunnel below the fault trace. There is no clear indication of Precambrian faulting, as in Hall Valley where pegmatite and aplite were emplaced in the fault zone. Nevertheless, the North Fork fault was projected into the tunnel from its surface trace as seen in aerial photographs (pl. 1, stas. $860+00$ to $874+69$ ). In the tunnel between stations $808+00$ and $886+00$, numerous slip 
surfaces parallel to foliation, as well as several prominent faults (some parallel and some oblique to foliation), were noted. These slip surfaces and faults indicate that the zone of the North Fork fault may be larger than that shown on plate 1. In Hall Valley, the fault is nearly normal to foliation, and movement was confined to a relatively narrow zone. But in the vicinity of the tunnel, the foliation is roughly parallel to the fault trace, and movement apparently occurred over a wide zone and involved the overturned limb ofthe anticline west of the Boulder Creek pluton.

Equal-area plots of fault poles for the various rock units or related tunnel intervals (pl. 1, area plots $B, E$, $H, O)$ show pole distributions similar to those in the corresponding foliation plots. The relationship suggests that much of the faulting was controlled by the planar fabric of the rock. However, faulting oblique to foliation commonly was noted in the mapping. The fault maxima define mean fault planes, which trend northeast, north, or east, and which dip at moderate to steep angles.

A total of 568 faults were mapped at tunnel level between East Portal and station 690+00. An arbitrary distinction was made in the mapping between major faults and minor faults, using a width of 1 foot for the zone of movement as a criterion for division. On this basis, 89 faults (less than 16 percent) are major faults. Their poles are effectively camouflaged by those of minor faults on the equal-area plots. Considered separately, the major faults are concentrated in two principal sets with average attitudes of N. $50^{\circ}$ W., $50^{\circ} \mathrm{NE}$. and N. $40^{\circ}$ E., $60^{\circ} \mathrm{NW}$. Striations on these faults indicate mainly strike-slip movement. The two sets appear to constitute a conjugate system related to the faults and veins of the mineral belt. The minor faults show less consistent attitudes, many being parallel to foliation. Others tend to be concentrated in easterly or northerly trending sets with relatively steep dips. Striations on these faults, particularly the northtrending sets, indicate dip-slip movement and suggest that the faults may be related to upthrusting of the basement core of the Front Range. Most of the faults are believed to have resulted from Laramide deformation.

\section{JOINTS}

The attitudes of more than 1,300 joints were measured in the portion of the tunnel considered in this chapter. Contoured equal-area plots of joint poles were prepared separately for each of the lithologic units (pl. 1, area plots $A, D, G, J, K, Q, R$ ). Engineering considerations required locating all fractures that could be construed to have a bearing on con- struction. Fractures showing prominent striations or appreciable gouge were mapped as faults; all others were classified as joints. Only joints that could be traced across the tunnel, or projected a comparable distance, were recorded.

Joints tend to be more numerous and to show greater pole dispersion in the granitic rocks than in the well-foliated rocks. All the diagrams show two or more significant pole concentrations. As with the faults, the mean fracture planes trend north, northeast, or east; a few trend northwest. However, a comparison of joint and fault diagrams for a given rock unit or tunnel interval indicates, for the most part, little or no relationship between the two patterns. Similar disparity is noted between the joint and foliation diagrams, which indicates that rock fabric had little or no influence on the jointing. These relationships suggest that the joints are dominantly of Laramide or post-Laramide origin and that they probably were formed mainly later than the faults, otherwise faulting would have been controlled to a large extent by preexisting fractures.

Harrison and Moench (1961, fig. 10) were able to identify a system of regional joints in the Central City-Idaho Springs area, about 20 miles northeast of the Roberts Tunnel. Longitudinal, cross, and diagonal joint sets were noted to conform to the axis of the Front Range. Joint data from the tunnel fail to define such a system. Joint diagrams for adjacent tunnel segments show marked dissimilarities, indicating that the fracture pattern changes with locality. Considered as a whole, the attitudes of mean fracture planes, corresponding to maxima and submaxima on the equal-area plots, show a random orientation. A trial plot of all joints showed a virtually isotropic distribution of poles.

\section{ENGINEERING PRACTICES IN RELATION TO GEOLOGY}

During the following excavation of the tunnel, an attempt was made to correlate lithologic and structural information obtained in geologic mapping with engineering data pertaining to supports, water flow, and progress of the tunneling operation. The latter data are shown graphically in relation to the geology on plates 1 and 2. Rock temperatures, measured at about 2,000-foot intervals by means of thermohms inserted into 15 -foot waterfilled holes drilled into the tunnel invert, are also recorded on plate 1 .

Where the tunnel rock was unstable and tended to cave, the opening was enlarged to accommodate steel supports. The supports used were 6-inch (rarely 8-inch) horseshoe-shaped " $H$ " ribs, spaced at intervals of 2-6 feet as required by local conditions (Chap. 
A, p. A8). Steel struts of the same dimension were installed to connect the ribs across the tunnel invert (or floor) where such additional support was necessary. Steel tie rods and wooden collar braces were used between the ribs, and wood lagging and wedges were placed as needed between the ribs and the rock surface. In many places, the supports were installed only as a safety precaution, and the supports bore little or no load. In other places, the steel ribs were deformed or displaced by postexcavation adjustments in the rock, and installation of new supports was required.

Blocky or slabby rock, which tended to result in rockfalls, was in places stabilized by rock bolting. In some cases, a combination of rock bolts and linkmesh screen was used to support rock that showed a tendency to ravel. Gunite was employed in certain sections of the tunnel to seal fractured rock or to prevent air slaking of rocks affected by hydrothermal alteration.

Inflows of water were encountered in places along fracture zones. Where such zones were suspected in advance of excavation, feeler holes were driven beyond the heading to intercept any potentially troublesome water courses. Substantial flows issuing from feeler holes or fractures were estimated in gallons per minute (pl. 1). For particularly wet sections of the tunnel, the total flow was estimated in gallons per minute per foot of tunnel.

Reports covering all phases of the operation were compiled on a semimonthly schedule. The rate of progress in excavating the tunnel was compiled for each heading in terms of the number of feet of advance per report period. From these data, the annual average progress for each heading and the total average progress for all headings were determined. The semimonthly progress for any portion of the tunnel may thus be compared with the averages, and the relationship of progress to geologic conditions may be observed (pl. 1).

Information on behavior of the rock in relation to blasting was obtained from tunnel sections taken normal to the centerline and spaced 10 feet apart. Tunnel radii were measured at $10^{\circ}$ intervals (Chap. C p. C11), starting with the vertical, by means of a sunflower and stadia rod. The sections provide a virtually continuous record of changes in the shape of the tunnel in relation to changes in rock structure and lithology. The total number of sections is very large, and a complete analysis of the data was not attempted. Instead, 21 tunnel intervals, representing as many different geological situations, were selected as samples for study (pls. 3-5). Because structural, lithologic, and engineering conditions changed rapidly along the tunnel route, the intervals were restricted to 130 or 140 feet in length, a practical limit for assuring approximate uniformity in a sample.

A composite plot was compiled for each sample interval, showing the payline (ideal) section, the arithmetic-mean section, the section with maximum overbreak, and a section giving the maximum tunnel radius obtained for each $10^{\circ}$ of arc. Trial plots showed that a section combining minimum radii coincides approximately with the payline. The area of each of the four sections was measured on the plot with a planimeter, and departures of areas of the arithmetic mean and maximum sections from the payline areas were calculated in terms of percent overbreak. The results are shown on plates 3-5.

The southeastern part of the tunnel is readily divided into five segments, each constituting a major structural or lithologic unit. The engineering conditions in relation to the geology of each segment are discussed separately, as they differ markedly from one segment to another.

\section{STATIONS $690+00$ to $808+00$ BIOTITE GNEISS AND SCHIST}

\section{GEOLOGY AND STRUCTURE}

This segment of the tunnel traverses the more gently dipping westerly limb of a large asymmetrical anticline and extends from the southeast margin of the Montezuma stock to the crest of the fold (pl. 1). Numerous small folds are superimposed on the limb of the large fold. The fold axes plunge west or northwest at about $45^{\circ}$. The rock is dominantly wellfoliated biotite gneiss and schist, but it does contain occasional massive bodies of pegmatite and Silver
Plume Granite. Between stations $756+00$ and $766+50$, microcline gneiss, in poorly foliated layers a few feet to more than 50 feet thick, are intercalated with biotite gneiss. A similar zone, containing thinner layers of microcline gneiss in biotite gneiss, was penetrated between stations $729+00$ and $733+00$.

Equal-area plots $A, B$, and $C$ on plate 1 show the pole distributions of joints, faults, and foliation planes in this segment of the tunnel. Typical attitudes of these structures in relation to the tunnel are 
GEOLOGY, EASTERN PART, (STATIONS $690+00$ TO 1238

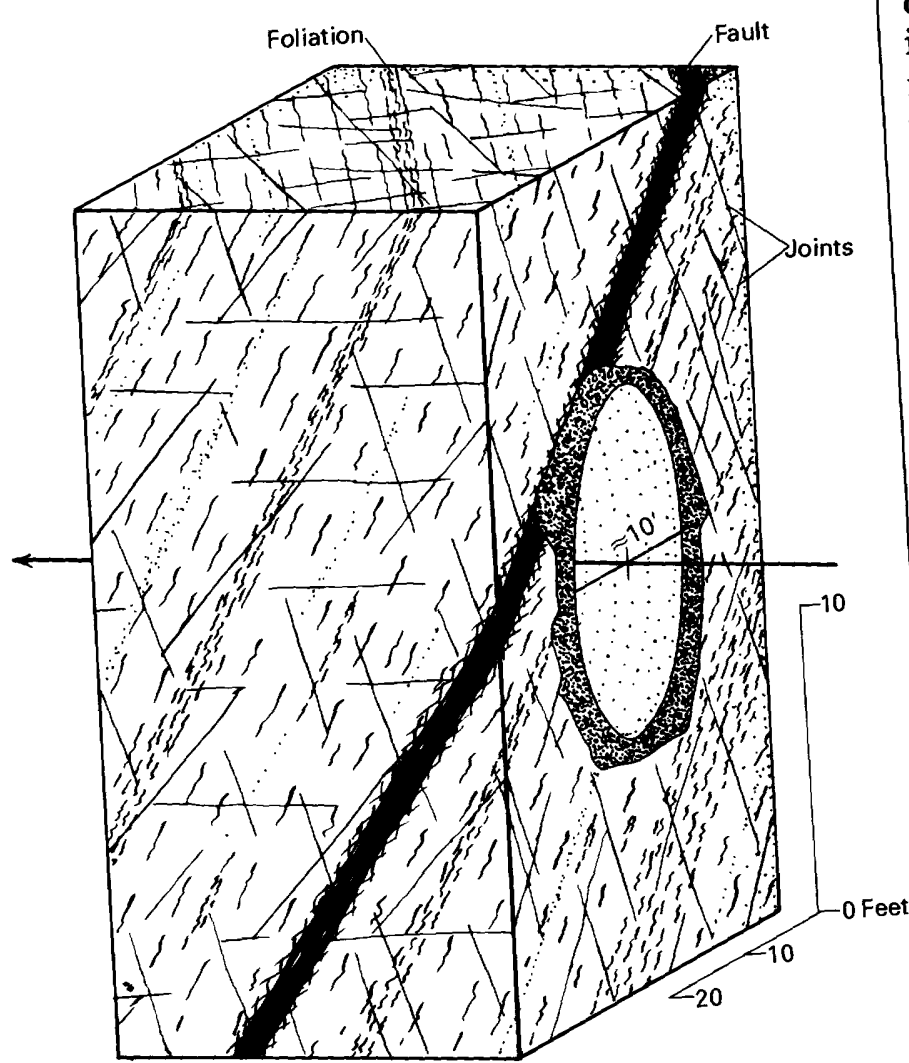

FIGURE 3-Diagram showing statistical relationships of tunnel foults, and joints in biotite gneiss and 年

schist between stations $690+$ direction of tunnel heading (N. $49^{\circ} 33^{\prime}$ W.).

shown diagrammatically in figure 3 . The tunnel is generally oblique to foliation, major faults, and most of the joints. One set of joints is nearly perpendicular to the tunnel axis (pl. 1, area plot $A$ ).

Although the equal-area plot for joints shows a markedly different pattern than that for faults, the pole concentrations are similar, which indicates that the major joint sets and fault sets are approximately parallel. This relationship is thought to be due to proximity to the Montezuma stock, in which similar fracture sets developed, with joints parallel to faults (Warner and Robinson, 1967, fig. 13). The situation is unlike that noted in the other tunnel segments to the southeast, where the fault and joint systems are apparently unrelated.

\section{WATERFLOWS AND GROUTING}

In places, this segment of the tunnel yielded large flows of high-pressure water from feeler holes and fractures (pl. 1, stas. $690+00$ to $808+00$ ). Much of the water was encountered between stations $755+00$ and $763+00$ (pl 2). The rock in this interval consists of contorted massiotite gneiss and schist, broken by interlayers of bists and joints. Throughout the interval, numerous is oblique or subparallel to the rock layers. High-pressure grouting was required intermittently to seal off the inflows of water.

The basal layer of the microcline gneiss unit was penetrated at station $766+43$. Although faulted, it yielded little water. A tightly folded layer between stations $764+15$ and $765+07$ was virtually dry. Microcline gneiss previously tunnel had given little or were wholly unexpected, and impending difficulties used continuously to test the rock in advance of the heading.

was first encountered in shot holes drilled from the heading at station $762+88$. Additional test holes indicated that the water was contained in a fault or fracture zone from 8 to 28 feet in advance of the heading. Gage tests showed pressures as high as $900 \mathrm{psi}$ (pounds per square inch) for flows of $300-500$ gallons per minute. Highpressure grouting was attempted, using back pressures of as much as $1,500 \mathrm{psi}$. At this pressure there was noticeable cracking of the rock face at the heading.

A concrete bulkhead was installed, and holes that were drilled through the bulkhead were used to grout the rock beyond. As a result of these operations, there was no advance of the heading for a period of 30 days. Subsequent excavation through the grouted section revealed no major fault but a zone of irregular fractures in microcline gneiss near its contact with schist. Grout seams as much as $3 / 4$-inch thick were noted in the fractured rock.

As excavation advanced from the bulkhead, feeler holes were employed almost continuously to test for water-bearing fractures in advance of the heading (pl. 1). The holes were made sufficiently long to maintain a natural bulkhead of firm rock from which to conduct high-pressure grouting in event substantial flows of water were encountered. Water flows amounting in places to as much as 500 gallons per minute were successfully grouted. A large amount of grout (1,395 cubic feet of cement) was used in the interval between stations $757+65$ and $755+95$, where microcline gneiss, biotite gneiss, and pegmatite are broken 65 , the feeler holes encountered

West of station $755+95$, water. The heading was biotite gneiss with ho 200 feet without incident advanced for more than which, though broken by several through rock, which, though then broke into the faults, was virtually dry. Wortion between stations tunnel along the invert portion betwe aggregating
$755+00$ and $756+00$ in flows agrating 
approximately 300 gallons per minute. The water issued from the contact zone between biotite gneiss and microcline gneiss along open fractures that had been closed and dry at the time of excavation a few days earlier. Fortunately, the volume of water was not sufficient to impede progress, and the flow of water was easily sealed off. The incident illustrates, how, even with judicious use of feeler holes, potentially large flows of water in fractured rock may go undetected.

Additional waterflows, amounting in places to as much as 500 gallons per minute, were encountered in feeler holes between stations $726+15$ and $725+60$, and again between stations $723+90$ and $722+70$ (pl. 1). A total of 4,716 cubic feet of cement was used in grouting the rock in these intervals. The waterflows were associated with minor faults and fracture zones in biotite gneiss. A zone of interlayered biotite gneiss and microcline gneiss, however, extends subparallel to, and in close proximity to, the tunnel in this vicinity. The gneissic zone is presumed to account for the water, although the zone was dry where previously penetrated by the tunnel.

The association of high-pressure water in this segment of the Roberts Tunnel with fractured competent rock layers (microcline gneiss) enclosed in less competent rock (biotite gneiss) suggests that such layers may behave as artesian aquifers in crystalline basement rocks of otherwise low permeability. Apparently, the water is contained in an irregular, interconnecting system of fractures, confined mainly to the competent layers, each such layer consisting of a mosaic of relatively large tabular blocks with fractured rock between the blocks. Except in the larger faults, the fractures do not extend far into the incompetent rock on either side. Where the competent layer is at a high angle to the tunnel, the tunnel may penetrate it through a major block with little or no inflow of water. Where the layer is oblique or subparallel to the tunnel in the zone of penetration, the probability of encountering water is increased. Such fractured layers may contain enormous quantities of water, (probably recharged along major faults extending to the surface). Even after grouting, reduced flows continued at some places in the Roberts Tunnel, with undiminished hydrostatic head, until the concrete lining was emplaced months after excavation.

\section{SUPPORTS}

Of the 11,800 feet of tunnel in this segment (stas. $690+00$ to $808+00$ ), 8,527 feet, or 72.3 percent, required support. Most of the steel supports were placed on 5foot centers, but in a few places, mainly at faults, they were placed on 2.5-foot centers (pl. 1). Struts were needed at only two such places, where a combination of fracturing and high-pressure water resulted in heavy ground.

Most of the rock bolts used in the tunnel were placed in this segment, along most of which the foliation in the gneiss and schist forms an angle of less than $45^{\circ}$ with the centerline. This situation resulting in a tendency for slabs of foliated rock to loosen along the arch, and the technique of suspension bolting (Thomas, 1962, p. 272) was employed to prevent rockfalls. In the tunnel segments southeast of station $808+00$, the planar rock fabric for the most part intersects the tunnel at a high angle, and rock bolting was not required.

Gunite was used intermittently to seal fractured rock or to prevent air slaking of altered rock. Gunite or rock bolts were employed mainly in those parts of the tunnel segment not supported by steel.

\section{OVERBREAK}

Four intervals, which represent typical geologic conditions, were selected for overbreak studies, and composite tunnel sections were compiled for each (pl. 3). The mean overbreak ranges from 13.66 to 21.72 percent, the average for all sections being 16.80 percent, a probable approximate average for this segment. The interval with largest mean overbreak (pl. $3 C$ ) is that in which microcline gneiss is interlayered with biotite gneiss and schist, combining competent and incompetent lithologies. The other intervals are mainly in biotite gneiss and schist. The composite sections show that overbreak tends to be asymmetrical, occurring mainly above the spring line, with the maximum tunnel radius normal or subnormal to the trace of foliation in the section. This suggests that foliation controls to a large extent the distribution of overbreak. The sections with maximum overbreak, however, generally can be related to faulting or jointing.

\section{PROGRESS}

The average progress rate for advancing the heading in this segment of the tunnel was 453.4 feet per semimonthly report period, compared to an average for the entire tunnel of 477.5 feet. The average progress rate between stations $808+00$ and $765+30$ was 630.7 feet, whereas the average between stations $765+30$ and $690+00$ was only 388.2 feet. Reduced progress in the later interval was due primarily to inflow of high-pressure water, requiring intermittent grouting and installation of the concrete bulkhead at station $762+88$. 


\section{Stations $808+00$ to $886+00$ North Fork Fault Zone}

\section{GEOLOGY AND STRUCTURE}

Between stations $808+00$ and $886+00$, the tunnel crosses the steeply inclined, overturned east limb of the large anticline noted in the previous section. The tunnel segment extends from the axis of the fold to the northwest margin of the Boulder Creek pluton (pl. 1). Linear elements, including the axes of minor folds, plunge northwest at about $60^{\circ}$. The rock is mainly biotite gneiss and schist, containing large to small bodies of pegmatite and aplite. Lithologic units on the west limb of the anticline are in part repeated on the east limb, notably the lower unit of microcline gneiss. Some additional units are present, including a thick layer of amphibolite between stations $856+00$ and $866+00$.

The mean attitudes of major joint sets, faults, and foliation planes between stations $808+00$ and $886+00$ are indicated on equal-area plots $D, E$, and $F$, plate 1 ; typical orientations of these structures with respect to the tunnel are shown in figure 4 . The foliation generally forms a large angle with the tunnel axis. The major joints, however, are mainly oblique to the tunnel, and one set strikes nearly parallel to the centerline. Comparison of plots $E$ and $F$, plate 1 , indicates that faults tend to be parallel to foliation, although the relationship pertains mainly to minor faults. Of the 120 faults noted in the tunnel segment, only 20 (those shown on pl. 1) are more than 1 foot wide. Most of these are oblique to foliation, and some are nearly parallel to the tunnel. Much of this tunnel segment is thought to constitute the North Fork fault zone, the movement having been dispersed along foliation planes, many of which show slickensides. The major faults are probably related to Laramide movement along the North Fork fault zone.

\section{WATERFLOW}

Feeler holes were used intermittently in faulted sections to guard against large inflows of water, but only small to moderate flows were encountered. Most of the flows diminished to insignificance soon after excavation, and none required grouting.

\section{SUPPORTS}

Approximately 6,805 feet of the 7,800 feet of tunnel in this segment, or 87.2 percent, required steel supports (stas. $808+00$ to $886+00$ ). The excessive support requirement is attributed to the high incidence of faults in these rocks. A majority of the supports were placed on 5 - or 6 -foot centers, but more than onefourth were spaced at 4.0, 2.5 or 2.0 feet (pl. 1). The closer spacing is generally related to intervals in which prominent faults appear. Struts were installed where faulting and hydrothermal alteration caused heavy or swelling ground; the total strutted intervals amounted to more than 900 feet of tunnel. Virtually all the unsupported intervals were treated with gunite.

\section{OVERBREAK}

Overbreak studies were made for three selected tunnel intervals, representing different lithologic and structural conditions. Composite tunnel sections for these intervals are shown on plate 3 . The mean overbreak ranges from 18.18 to 25.3 percent, the average being 21.15 percent. The largest mean over-

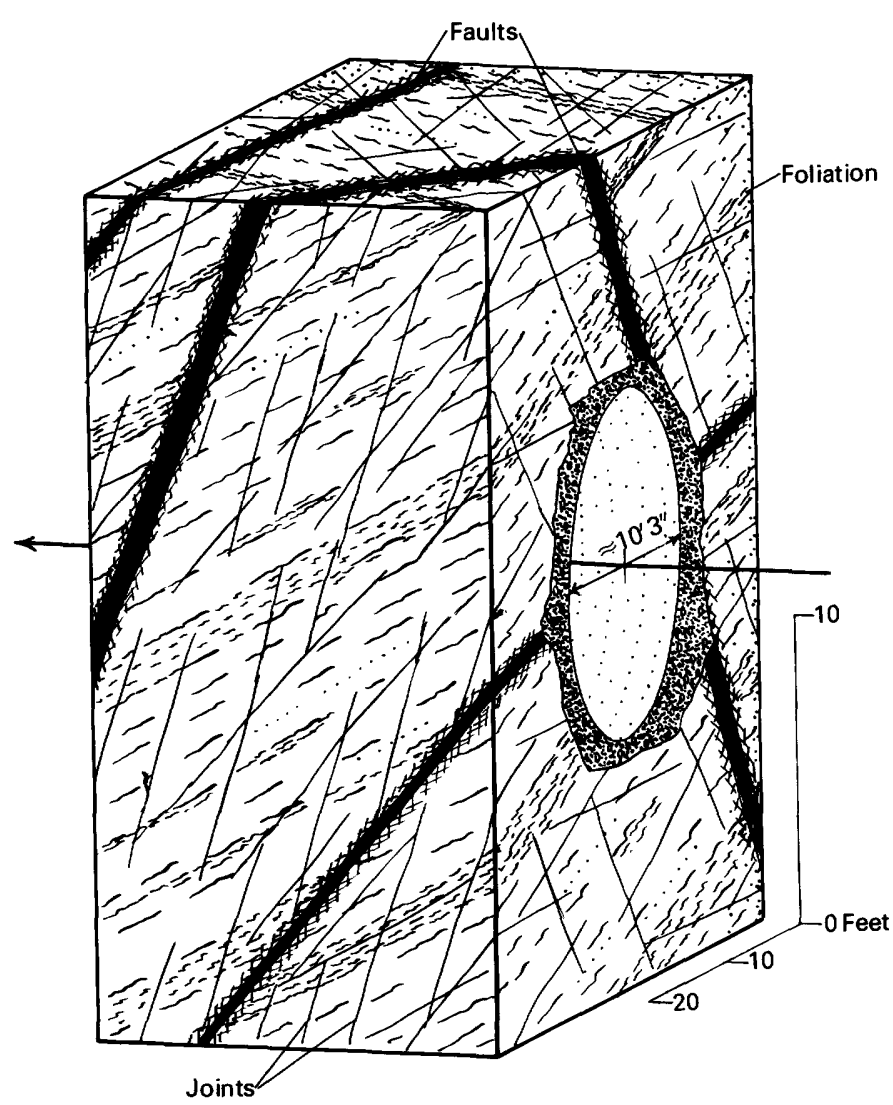

FIGURE 4.-Diagram showing statistical relationships of tunnel and attitudes of foliation, faults, and joints in biotite gneiss and schist between stations $808+00$ and $886+00$. Arrow indicates direction of tunnel heading (N. $49^{\circ} 33^{\prime}$ W.). 
break is for the interval in the thick amplibolite layer (pl. $3 B$, stas. $863+60$ to $864+90$ ). This rock is more competent than the biotite gneiss, in which it is enclosed, and broke with a blocky outline due to numerous irregular fractures. The section with greatest overbreak, 51.34 percent (pl. $3 F$, stas. $849+00$ to $850+40$ ), is at the contact between sheared biotite gneiss and schist and a broken and altered aplite dike; there stoping in the arch extended several feet above the payline. Inspection of the composite sections suggests that the overbreak tends to be assym. metrical and was controlled in part by foliation.

\section{PROGRESS}

The average progress per semimonthly report period was 559.4 feet, compared to an average of 477.5 feet for the entire tunnel and to an average of 686.4 feet for advance of the East Portal heading during 1958. Slowest progress occurred in strongly faulted and altered sections where closely spaced steel ribs and struts were required. Progress was slowed also, owing to variable lithology and the blocky character of the rock, where microcline gneiss with interlayers of biotite gneiss was penetrated between stations $819+50$ and $817+50$.

\section{Stations $886+00$ to $977+00$ Boulder Creek Pluton}

\section{GEOLOGY AND STRUCTURE}

The tunnel passes through the Boulder Creek pluton between stations $886+00$ and $977+00$ (pl. 1). The granite is mainly coarse grained and poorly foliated. The marginal parts of the pluton consist essentially of granite with but few dikes or inclusions of other rocks. The central part contains large to small tabular inclusions of biotite gneiss and schist, together with dikes of Silver Plume Granite, pegmatite, and aplite. The dikes and inclusions are oriented generally parallel to foliation. Most of the faults encountered in the pluton occur in the central part; the marginal parts of the pluton are in general more strongly jointed.

Equal-area plots for joints, faults, and foliation are shown on plate 1 (stas. $886+00$ to $977+00$ ). The mean foliation plane in the granite (pl. 1 , area plot $K$ ) strikes approximately normal to the tunnel axis and dips about $50^{\circ} \mathrm{NW}$.; joint poles are widely dispersed, and concentrations are poorly defined (pl. 1, area plot J). One of the more prominent joint sets is nearly parallel to the tunnel axis, and another is nearly normal to the mean foliation. Faults are too few in the granite to be statistically significant, but they tend to be parallel to foliation in this part of the tunnel (pl. 1, area plot $H$ ). This is particularly true of the minor faults, which are far more numerous than the major ones. Typical orientations of the planar structures with respect to the tunnel axis are shown diagrammatically in figure 5.

\section{SPALLING AND POPPING ROCK}

Spalling or popping rock was encountered at several places along the tunnel route through the Boulder Creek pluton. The rock exfoliated in a thin zone concentric with the tunnel opening, particularly along the arch. Lens-shaped slabs several inches thick broke in to the tunnel, commonly with explosive violence. For the most part, the slabs were clearly unrelated to the rock fabric or to preexisting fractures. The spalling occurred generally within several hours after excavation. The major occurrences were between stations $963+50$ and $967+50$, and between stations $899+00$ and $901+00$. These intervals are respectively in the southeastern and northwestern marginal parts of the Boulder Creek pluton. Each is roughly 1,000 feet from the contact and marks a transition from strongly jointed and foliated granite in the marginal zone to more massive rock in the central part. No spalling or popping was noted where faults, dikes, and biotite gneiss inclusions are common.

The spalling and popping phenomena are regarded as mild rock bursts, commonly attributed to redistribution of stresses within rock masses adjacent to an underground opening (Bucky, 1945, p. 619-623). Behavior similar to that in the Roberts Tunnel was noted in parts of the Delaware aqueduct, New York, by Bird (in Bucky, 1945, p. 589-593), who attributed the "stress fracturing" to residual elastic strains inherited from ancient tectonic movements. In the Prospect Mountain Tunnel (Colorado-Big Thompson project), Colo., Olsen (1957, p. 194) measured stresses two to six times greater than could be accounted for by overburden. Rock bursts of varying intensity have been noted in granite quarries at Barre, Vt., (White, 1946) and have been attributed to the tendency of the granite, originally deeply buried, to expand into the excavations.

The Boulder Creek Granite in the Roberts Tunnel probably was some thousands of feet beneath the regional surface in Late Cretaceous time. It has since been subjected to strong diastrophism and has moved 


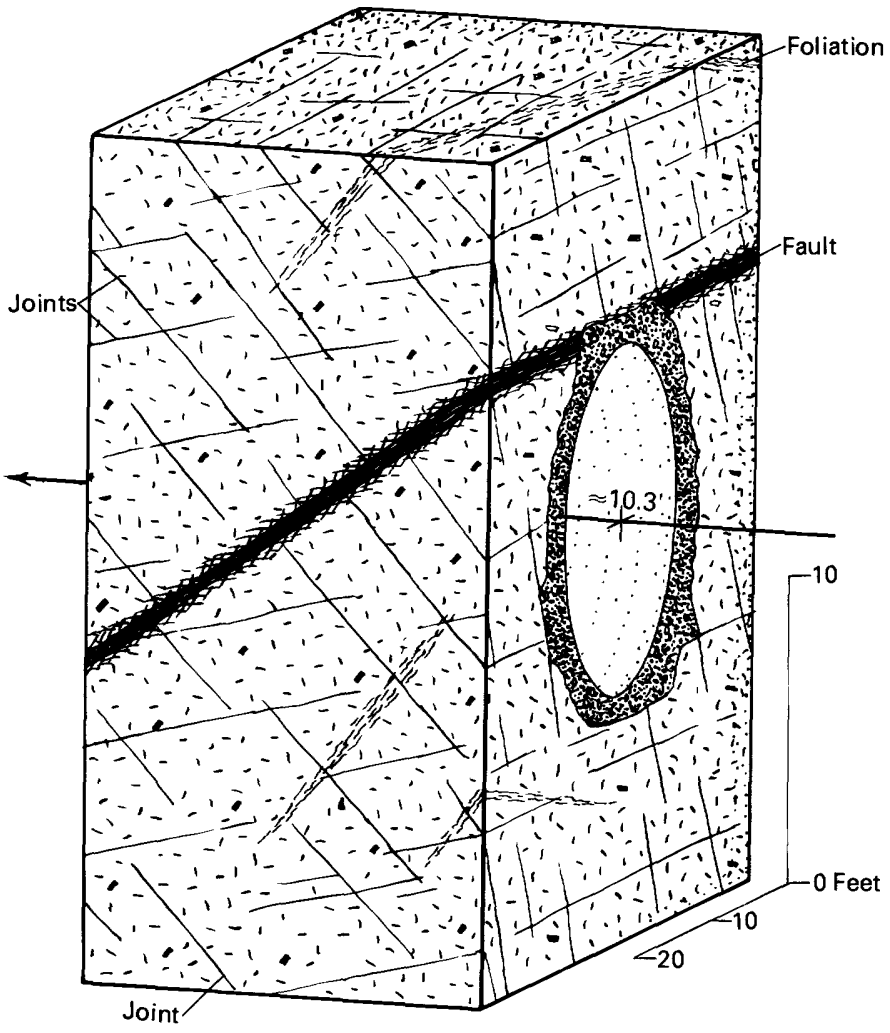

FIGURE 5.-Diagram showing statistical relationships of tunnel and attitudes of foliation, faults, and joints in Boulder Creek Granite between stations $886+00$ and $977+00$. Arrow indicates direction of tunnel heading (N. $49^{\circ} 33^{\prime}$ W.).

through a vertical interval of several miles. Stresses resulting from deformation and decompression of the granite were largely relieved by jointing and by adjustments along faults, contacts, and foliation planes. Where the granite is massive and virtually unbroken, residual stresses of considerable magnitude may be expected. Such conditions apparently account for the localization of spalling and popping rock in the tunnel.

\section{SUPPORTS}

Steel supports were installed in 59.2 percent, or 5,384 of the 9,100 feet, of the tunnel segment in Boulder Creek Granite (stas. $886+00$ to $977+00$ ). Supported rock accounts for 56.6 percent of the interval between stations $886+00$ and $915+00$, for 63.3 percent of the interval between stations $915+00$ and $945+00$, and for 57.6 percent of the interval between stations $945+00$ and $977+00$. Respectively, the three intervals represent roughly the western marginal, central, and eastern marginal parts of the Boulder Creek pluton. It is of interest to note that the central part which is structurally and lithologically the most heterogeneous, required approximately 6 percent more support than the marginal parts. A significant amount of the support in the marginal parts was installed as protection against spalling or popping rock. The dominant spacing of the steel supports is at 5- or 6foot intervals; a few were placed on 2.5- or 4-foot centers, mainly at faults or contacts (pl. 1). Gunite was used sparingly in some intervals not supported by steel.

\section{OVERBREAK}

Composite tunnel sections were compiled and overbreak was calculated for five selected intervals in the Boulder Creek Granite (pl. 4). The average overbreak for the five sections, a probable average for the tunnel segment, is 11.2 percent. The range in mean overbreak is from 5.55 to 15.84 percent. The two intervals in unsupported rock (pl. $4 B, E$ ) show markedly less overbreak than those in which supports were required. Sections with maximum overbreak, amounting to as much as 27.76 percent, occur in closely jointed or faulted rock. In all the composite sections, the mean overbreak is roughly symmetrical, indicating a generally isotropic behavior of the granite in response to blasting. Local asymmetry of overbreak appears to be related to foliation or fractures or to a combination of the two.

\section{PROGRESS}

The average rate of progress in advancing the tunnel heading through the granite was 738.2 feet per semimonthly report period, compared to an average of 686.4 feet for advance of the East Portal . heading during 1958. The rate for the central part of the Boulder Creek pluton was 707 feet, compared to the 729.4 feet for the eastern marginal part and 801.4 feet for the western marginal part. A close correlation between geologic conditions, support requirements, and progress rate is indicated.

\section{Stations $977+00$ to $1083+00$ Microcline Gneiss and Migmatite}

\section{GEOLOGY AND STRUCTURE}

This segment of the tunnel is in folded and faulted metamorphic rocks that lie between the Boulder
Creek pluton and the main body of Silver Plume Granite (pl. 1). Between stations $977+00$ and $1014+30$, the rock is microcline gneiss with some pegmatite and infrequent layers of biotite gneiss. Foliation in 
the gneiss strikes northeast, approximately normal to the tunnel axis and dips northwest at an average angle of about $35^{\circ}$. The remainder of the segment between stations $1014+30$ and $1083+00$, is in migmatite, which contains a few layers of microcline gneiss and amphibolite-also dikes or lenses of pegmatite and Silver Plume Granite. Foliation in the migmatite strikes east and has an average dip of about $60^{\circ} \mathrm{N}$. The relationship of the microcline gneiss to the migmatite is obscure, in that the two units are separated by a mass of pegmatite at tunnel level and by an irregular body of Silver Plume Granite at the surface. However, surface mapping suggests that the units are conformable and in normal stratigraphic sequence. The contact is warped by a broad, shallow syncline (pl. 1), the axis of which plunges northeast at a moderate angle.

Equal-area plots on plate 1 depict the mean attitudes of joints, faults, and foliation planes. A typical

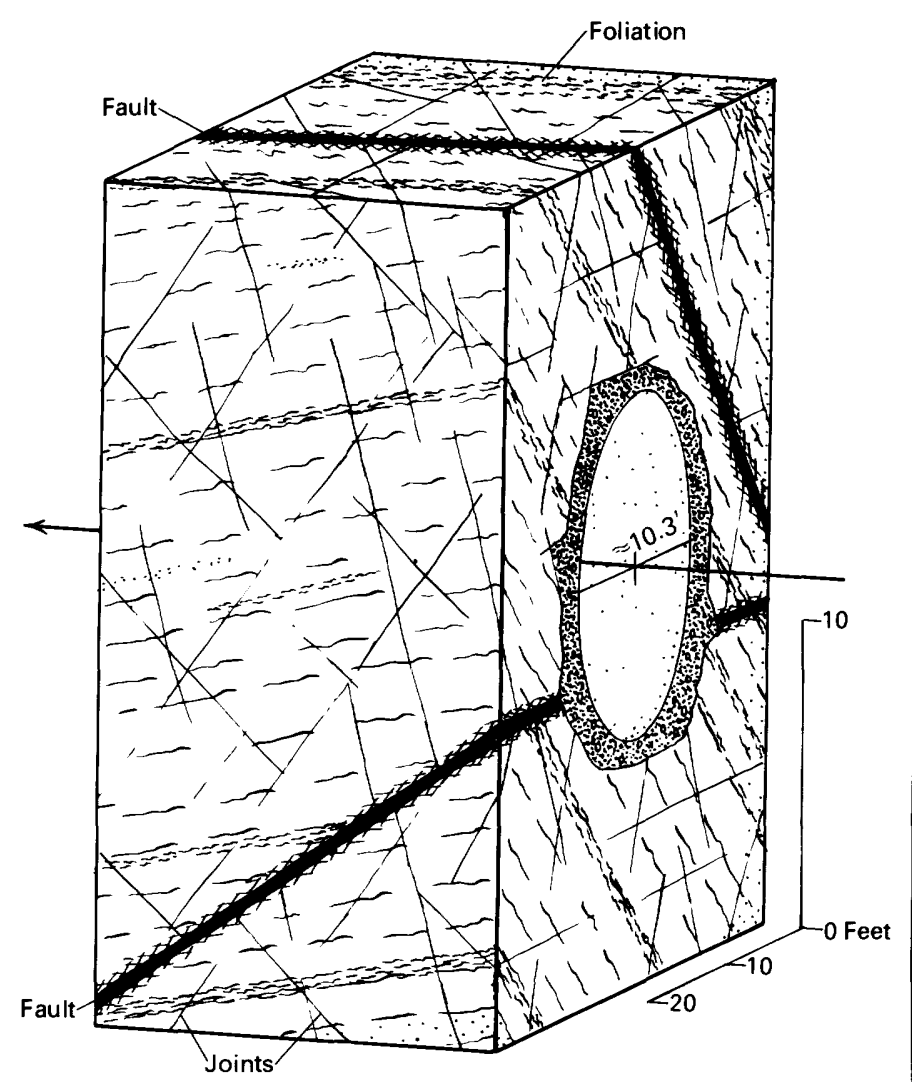

FIGURE 6.-Diagram showing statistical relationships of tunnel and attitudes of foliation, faults, and joints in metasedimentary rocks between stations $977+00$ and $1083+00$. Arrow indicates direction of tunnel heading (N. $49^{\circ} 33^{\prime}$ W.). orientation of the tunnel with respect to these structures is shown diagrammatically in figure 6. Faults in this part of the tunnel tend to be parallel to foliation, although this tendency does not hold for many of the major ones. The number of major and minor faults in the migmatite is much greater than in the microcline gneiss. The joint pattern shows little or no relationship to the planar rock fabric. Joints of the principal set strike northeast across the tunnel and dip southeast at a moderate angle. Other prominent joints are steep and strike north, in directions oblique to the tunnel axis.

\section{SUPPORTS}

The aggregate of steel-supported intervals in the tunnel segment amounts to 5,670 feet, or 53.5 percent of the 10,600 feet of tunnel (stas. $977+00$ to $1083+00$ ). Only 29.5 percent of the interval in the microcline gneiss unit required support, compared to 66.5 percent of the interval in the migmatite unit. The difference is thought to be due primarily to the much higher incidence of faulting in the migmatite, although the differences in lithology and in attitude of foliation with respect to the tunnel axis probably were contributing factors. The steel supports are dominantly on 5-foot centers in the migmatite and are entirely so in the microcline gneiss. Spacing of supports at 2.5 feet was required in a few of the faulted intervals in migmatite. Gunite was used sparingly in unsupported intervals in microcline gneiss and more extensively in migmatite.

\section{OVERBREAK}

Six intervals in the tunnel segment (stas. $977+00$ to $1083+00$ ) were selected for overbreak studies; composite tunnel sections for these intervals are shown on plates $4 F-4 H$ and $5 A-5 C$. Three of the intervals are in microcline gneiss (pl. $4 F-H$ ), two are in migmatite (pl. $5 B, C$ ), and one is in the large pegmatite mass between these units (pl. 5A). Three intervals are in supported rock and three in unsupported rock. The range in mean overbreak is from 7.13 percent in microcline gneiss to 12.58 percent in migmatite; the average for all sections is 10.83 percent. Mean overbreak is appreciably less in unsupported rock than in supported rock. The discrepancies between mean and maximum overbreak sections are larger in the migmatite than in the microcline gneiss and roughly the same in the pegmatite interval as in migmatite. 
The massive pegmatite shows a nearly summetrical overbreak pattern. A tendency toward asymmetry of overbreak, apparently controlled mainly by foliation, is slight in the microcline gneiss and is more pronounced in the migmatite. Although the number of sections studied is too few to be definitive, appreciable differences in the behavior of the rock types with respect to blasting are indicated.

\section{PROGRESS}

The progress rate for this tunnel segment averaged 706.5 feet per semimonthly report period. The average for the microcline gneiss unit was 737.3 feet, compared to 691.1 feet for the migmatite unit. Variations in the progress rate correlate in a general way with geologic conditions and support requirements (pl. 1, stas. $977+00$ to $1083+00$ ).

\section{Station $1083+00$ to $1238+58$ (East Portal) Silver Plume Granite}

\section{GEOLOGY AND STRUCTURE}

The major part of the tunnel segment is in Silver Plume Granite, which contains irregular pendants and inclusions of amphibolite (pl. 1). The granite is generally poorly foliated and in places quite massive. The amphibolite is distinctly layered, locally containing beds of quartzite and calc-silicate rock, and is commonly well foliated. Lineation is, for the most part, poorly developed. Contacts with the granite are in places discordant and are generally marked by pegmatite rims less than a foot to several feet thick. Folds with wavelengths and amplitudes ranging from a few inches to more than a thousand feet are conspicuous in the amphibolite. The axes of minor folds plunge generally northeast or southwest at small to large angles. the initial folds in the amphibolite appear to have been rotated during emplacement of the granite.

Between approximately station $1200+00$ and the East Portal (sta. 1238+58), is mainly migmatite, but it does contain a few layers of amphibolite and dikes and apophyses of granite and pegmatite. Surface mapping indicates that the migmatite is related by anticlinal folding to the migmatite unit northwest of station $1083+00$. This interpretation places the granite-amphibolite complex in the core of a large anticline; the migmatite near the East Portal is then on the overturned easterly limb of the fold.

Equal-area plots $N, O$, and $P$ on plate 1 depict the mean attitudes of joints, faults, and foliation planes; a typical relation of the tunnel to these structures is shown diagrammatically in figures 7 and 8. Data shown on equal-area plots $N$ and $O$ (pl. 1) suggest that faults tend to be parallel to foliation, although the tendency is not as pronounced as in other parts of the tunnel. More than 25 percent of the faults in this segment are major faults, which generally are not related to foliation. Equal-area plots $Q$ and $R$ (pl. 1) compare joints in the metasedimentary rocks with those in the granite. The principal joint set in the metasedimentary rocks strikes normal to the tunnel axis and dips steeply southeast; joint sets in the granite are mainly oblique or parallel to the tunnel axis.

\section{ENGINEERING DATA}

Detailed engineering data are lacking for the interval between stations $1138+72$ and $1238+58$ (East Portal). This part of the tunnel was excavated during the period 1946-56 by the Denver Board of Water Commissioners on a restricted 1-shift-per-day basis. Progress averaged less than 1,000 feet per year, and steel supports were required for only 16.7 percent of the interval. The remainder of the tunnel segment was excavated by Blue River Constructors who operated on a full-scale, 3-shift-per-day basis. Progress was at the rate of 600.9 feet per semimonthly report period, and steel supports were required for 32.8 percent of the interval. The marked increase in the support requirement cannot be attributed to a change in geologic conditions and is related mainly to the increase in rate of progress. The leisurely rate of excavation southeast of station $1138+72$ permitted the rock to approach a state of equilibrium between shifts. This was not true northwest of station 1138 +72 where advance of the heading was rapid and constant.

Composite tunnel sections were compiled for three selected intervals between stations $1083+00$ and $1138+72(\mathrm{pl} .5 D-F)$. In one interval the rock is amphibolite cut by pegmatite dikes; in the other two it is 


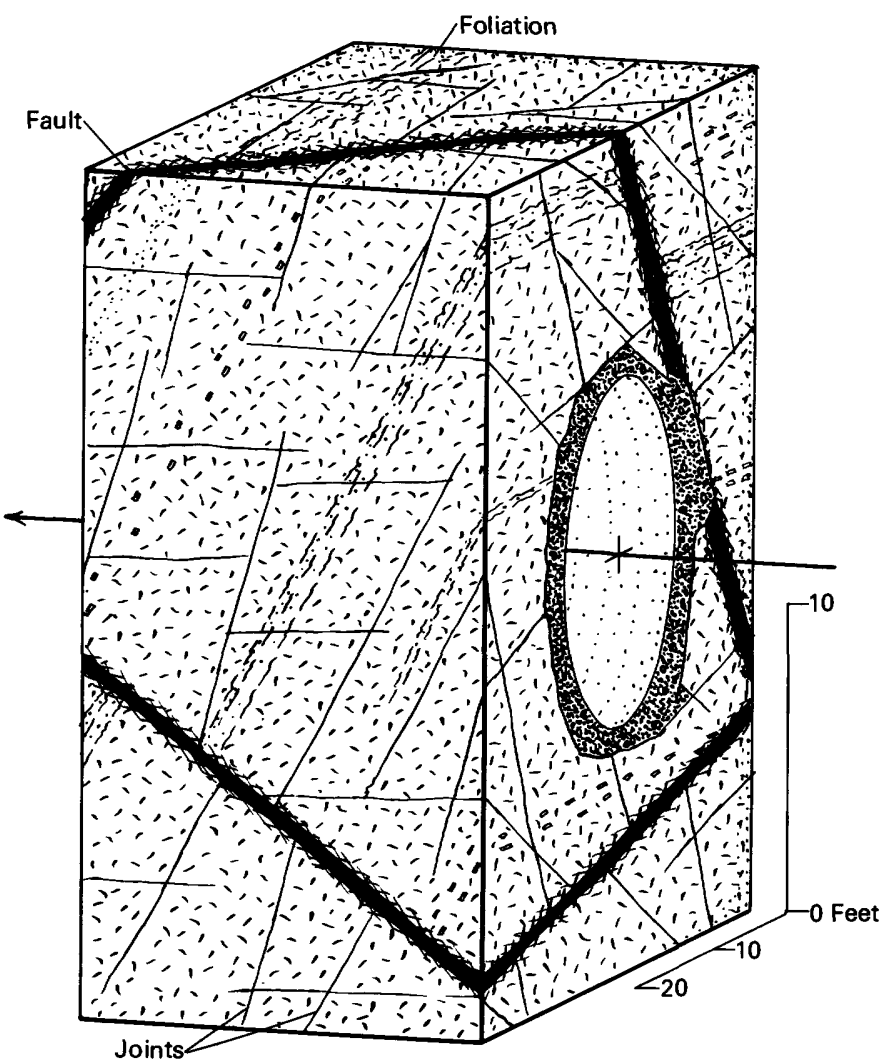

FIGURE 7.-Diagram showing statistical relationships of tunnel and attitudes of foliation, faults, and joints in Silver Plume Granite between stations $1083+00$ and $1238+58$ (East Portal). Arrow indicates direction of tunnel heading (N. $49^{\circ} 33^{\prime} \mathrm{W}$.).

Silver Plume Granite. Mean overbreak for the sections ranges from 9.68 percent in granite to 11.42 percent in amphibolite; the average is 10.7 percent. The section with maximum overbreak of 24.18 per-

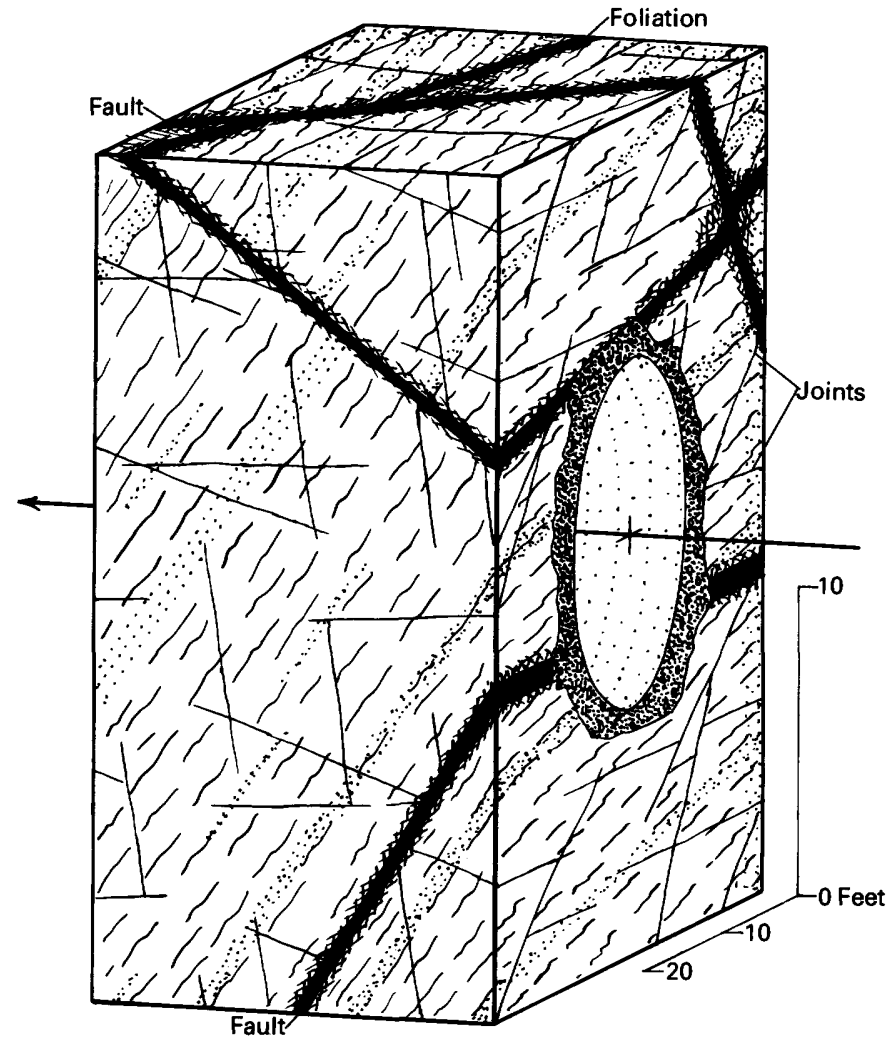

FIGURE 8.-Diagram showing statistical relationships of tunnel and attitudes of foliation, faults, and joints in metasedimentary rocks between stations $1083+00$ and $1238+58$ (East Portal). Arrow indicates direction of tunnel heading (N. $49^{\circ} 33^{\prime}$ W.).

cent (pl. $5 E$ ) is in faulted granite which contains large inclusions of amphibolite. The sections show no marked tendency for overbreak to be assymmetrical.

\section{EVALUATION OF GEOLOGY AND ENGINEERING PRACTICES}

\section{CRITERIA FOR ESTIMATING THE BULK PROPERTIES OF ROCK}

It has long been recognized that the gross mechanical behavior of rock masses cannot be predicted solely on the basis of laboratory tests applied to small samples of the rock materials. Techniques have been developed for testing the bulk properties of large masses of rock in situ (Olsen, 1957; Swain, 1962 ; Judd, 1964, p. 340-448) by use of strain gages, seismometers, and other geophysical equipment. Studies of the sort required are expensive and time consuming. They are not readily coordinated with the schedule of a full-scale tunneling operation and were not used during construction of the Roberts Tunnel. However, the tunneling operation provided a wealth of geologic and engineering data, which were supplemented subsequently by laboratory investigations. A means was sought to develop from these data certain parameters which would enable a quantitative comparison of the gross geologic, geophysical, and engineering properties of the rock units involved. The parameters selected are discussed in the following paragraphs, and a correlation of the results obtained from their application is given in the final section of this chapter.

\section{GEOPHYSICAL PARAMETERS}

Thermal (pl. 1), magnetic, and gravimetric observations were made throughout the tunnel during construction. Analyses of these data are not included 
TABLE 1.-Physical properties of Precambrian rocks

[Leaders (..........) indicate no data obtained. Analysts: D.R. Cunningham, V. Moreland, and E.E. Monk]

\begin{tabular}{|c|c|c|c|c|c|c|c|c|c|}
\hline Rock type & Samples tested & Range & $\begin{array}{l}\text { Porosity } \\
\text { (percent) }\end{array}$ & $\begin{array}{c}\text { Grain } \\
\text { density }^{1}\end{array}$ & $\begin{array}{l}\text { Dry bulk } \\
\text { density }^{1}\end{array}$ & $\begin{array}{c}\text { Young's } \\
\text { modulus }{ }^{2} \\
(E)\end{array}$ & $\begin{array}{l}\text { Rigidity }^{2} \\
\qquad(\mu)\end{array}$ & $\begin{array}{l}\text { Poisson's } \\
\text { ratio } \\
(\Sigma)\end{array}$ & $\begin{array}{c}\text { Bulk } \\
\text { modulus }^{2} \text { a } \\
(K)\end{array}$ \\
\hline $\begin{array}{l}\text { Silver } \\
\text { Plume } \\
\text { Granite. }\end{array}$ & ${ }^{1} 16$ & $\begin{array}{c}\text { Maximum } \\
\text { Minimum } \\
\text { Average }\end{array}$ & $\begin{array}{r}2.60 \\
.30 \\
.95\end{array}$ & $\begin{array}{l}2.73 \\
2.64 \\
2.67\end{array}$ & $\begin{array}{l}2.68 \\
2.62 \\
2.64\end{array}$ & $\begin{array}{r}11.71 \\
5.76 \\
8.64\end{array}$ & $\begin{array}{l}4.70 \\
2.51 \\
3.47\end{array}$ & $\begin{array}{r}0.367 \\
.120 \\
.243\end{array}$ & 7.00 \\
\hline $\begin{array}{l}\text { Boulder } \\
\text { Creek } \\
\text { Granite. }\end{array}$ & 6 & $\begin{array}{c}\text { Maximum } \\
\text { Minimum } \\
\text { Average }\end{array}$ & $\begin{array}{l}.70 \\
.30 \\
.35\end{array}$ & $\begin{array}{l}2.69 \\
2.62 \\
2.65\end{array}$ & $\begin{array}{l}2.67 \\
2.61 \\
2.63\end{array}$ & $\begin{array}{l}9.50 \\
5.10 \\
6.57\end{array}$ & $\begin{array}{l}4.15 \\
2.20 \\
2.89\end{array}$ & $\begin{array}{l}.253 \\
.019 \\
.134\end{array}$ & 3.74 \\
\hline $\begin{array}{l}\text { Pegmatite } \\
\text { and } \\
\text { aplite. }\end{array}$ & 3 & $\begin{array}{c}\text { Maximum } \\
\text { Minimum } \\
\text { Average }\end{array}$ & $\begin{array}{l}.90 \\
.70 \\
.80\end{array}$ & $\begin{array}{l}2.63 \\
2.63 \\
2.63\end{array}$ & $\begin{array}{l}2.61 \\
2.61 \\
2.61\end{array}$ & $\begin{array}{l}8.26 \\
5.08 \\
6.33\end{array}$ & $\begin{array}{l}3.31 \\
2.42 \\
2.74\end{array}$ & $\begin{array}{l}.248 \\
.047 \\
.142\end{array}$ & 3.69 \\
\hline $\begin{array}{l}\text { Microcline } \\
\text { gneiss. }\end{array}$ & ${ }^{5} 5$ & $\begin{array}{c}\text { Maximum } \\
\text { Minimum } \\
\text { Average }\end{array}$ & $\begin{array}{r}1.40 \\
.60 \\
1.10\end{array}$ & $\begin{array}{l}2.80 \\
2.65 \\
2.69\end{array}$ & $\begin{array}{l}2.78 \\
2.62 \\
2.66\end{array}$ & 12.53 & 4.90 & .279 & 11.82 \\
\hline $\begin{array}{l}\text { Biotite } \\
\text { gneiss and } \\
\text { schist. }\end{array}$ & 4 & $\begin{array}{l}\text { Maximum } \\
\text { Minimum } \\
\text { Average }\end{array}$ & $\begin{array}{l}.80 \\
.50 \\
.70\end{array}$ & $\begin{array}{l}2.92 \\
2.67 \\
2.79\end{array}$ & $\begin{array}{l}2.90 \\
2.65 \\
2.77\end{array}$ & $\begin{array}{r}10.44 \\
5.59 \\
7.66\end{array}$ & $\begin{array}{l}4.35 \\
2.31 \\
3.27\end{array}$ & $\begin{array}{l}.234 \\
.096 \\
.177\end{array}$ & 11.95 \\
\hline Amphibolite & 2 & $\begin{array}{l}\text { Maximum } \\
\text { Minimum } \\
\text { Average }\end{array}$ & $\begin{array}{l}.30 \\
.30 \\
.30\end{array}$ & $\begin{array}{l}2.92 \\
2.92 \\
2.92\end{array}$ & $\begin{array}{l}2.91 \\
2.91 \\
2.91\end{array}$ & $\begin{array}{l}11.23 \\
10.94 \\
11.09\end{array}$ & $\begin{array}{l}4.57 \\
4.50 \\
4.54\end{array}$ & $\begin{array}{l}.246 \\
.198 \\
.222\end{array}$ & 8.32 \\
\hline Migmatite & 3 & $\begin{array}{l}\text { Maximum } \\
\text { Minimum } \\
\text { Average }\end{array}$ & $\begin{array}{r}2.10 \\
.80 \\
1.33\end{array}$ & $\begin{array}{l}2.85 \\
2.63 \\
2.72\end{array}$ & $\begin{array}{l}2.83 \\
2.57 \\
2.69\end{array}$ & $\begin{array}{r}11.19 \\
4.42 \\
6.91\end{array}$ & $\begin{array}{l}4.13 \\
1.80 \\
2.60\end{array}$ & $\begin{array}{l}.366 \\
.228 \\
.316\end{array}$ & 7.80 \\
\hline
\end{tabular}

${ }^{1}$ Values given in grams per cubic centimeter.

${ }^{2}$ Values given in pounds per square inch $\times 10^{6}$.

${ }^{3}$ Calculated from average values for other elastic constants.
4All samples from Straight Creek Tunnel.

${ }^{5}$ Complete data for only one sample from Straight Creek Tunnel. in this report. However, the data do not appear to have a direct bearing upon engineering problems related to tunnel construction.

Numerous studies have been made to determine the relationship in rocks of various physical properties to engineering behavior (Obert and others, 1946; Windes, 1949, 1950; Mielenz, 1955; Blair, 1955, 1956). In the present investigation, porosity, density, and elastic constrants were determined for sample suites from each of the major rock types (table 1). Poisson's ratio $(\sigma)$, Young's modulus $(E)$, and rigidity or shear modulus $(\mu)$ were determined by the bar resonance method. The bulk modulus, or modulus of incompressibility $(K)$, was calculated from the other elastic constants, averaging the values obtained from the following equations:

$$
K=\frac{2 \mu(1+\sigma)}{3(1-2 \sigma)} \quad K=\frac{E}{3(1-2 \sigma)}
$$

Some of the samples obtained from the Roberts Tunnel proved unsuitable for analysis, and the results were supplemented, where possible, by results obtained for samples of the same rock types from the Straight Creek highway tunnel (Scott and others, 1968; Robinson and others, 1974), a few miles to the north.

Data from table 1 are shown graphically in figure
9. Trial plots were made using values for each property as abscissas and values for each of the other properties as ordinates; the plots shown are those which give the best fits for all values. The values for amphibolite and migmatite are seemingly anomalous, perhaps owing to inadequate sampling. Data in table 1 indicate that the anticipated inverse correlation between porosity and dry bulk density is poor; however, the rock with highest density (amphibolite) has the lowest porosity. Two density curves are suggested in figure $9 A$ : a flat curve (D) for the more feldspathic rocks and a steeper curve ( $\left.D^{\prime}\right)$ for the more ferromagnesian rocks. The porosity curve suggests that porosity varies directly with values of Poisson's ratio for these rocks. Comparison of figures $9 A$ and $9 B$ implies a similar correlation of porosity with other elastic constrants, a situation that is theoretically improbable for some. Trial plots of the elastic constants against porosity values showed no simple correlation. In general, the properties of these rocks correspond to those of similar basement rocks from other regions (Wuerker, 1956).

\section{ENGINEERING PARAMETERS}

As noted previously, composite tunnel sections were compiled for 21 selected tunnel intervals representing different structural and lithologic conditions. 

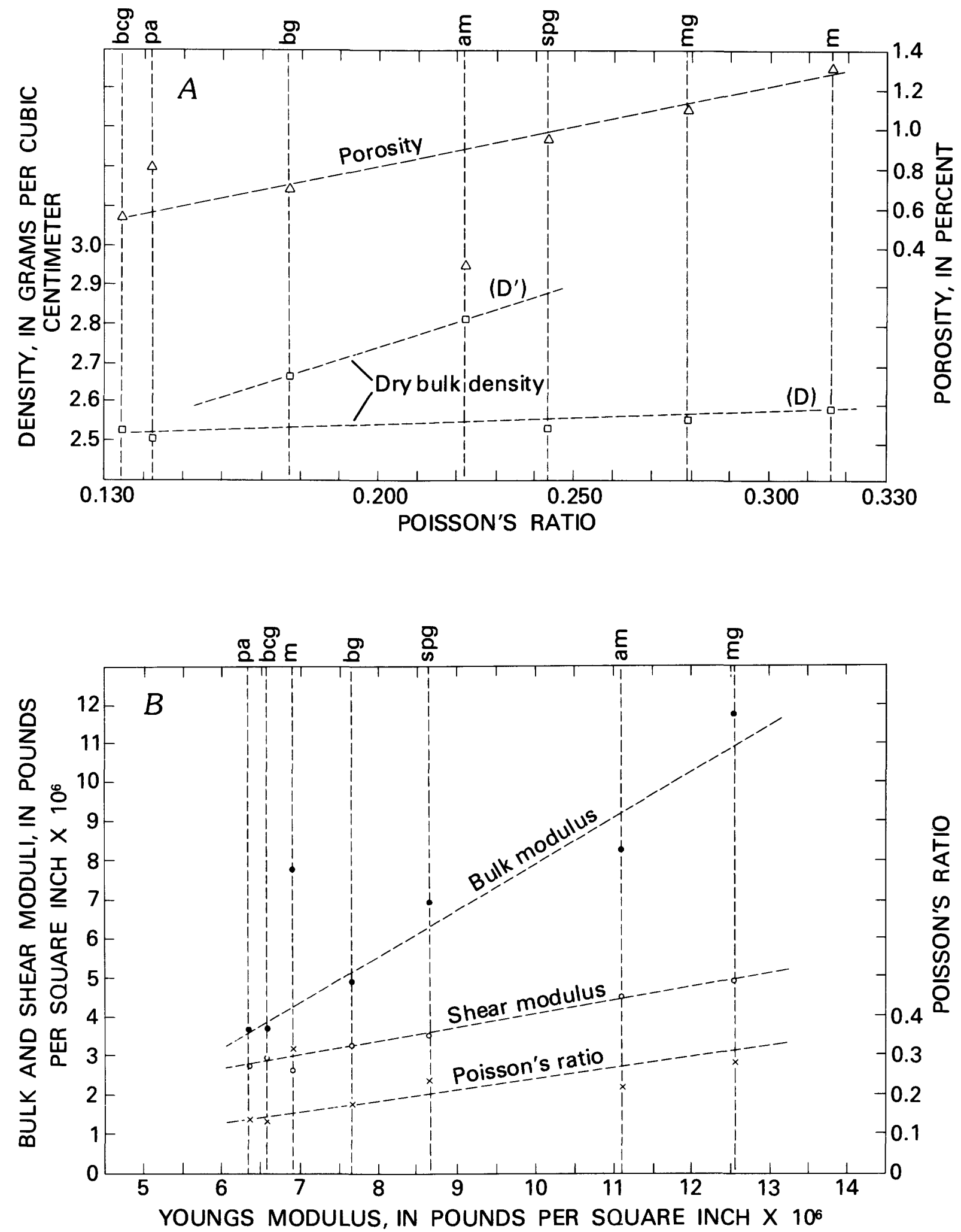

FIGURE 9.-Relation of elastic properties, density, and porosity in Precambrian rocks, Roberts Tunnel, Colorado. pa, pegmatite and aplite; bc, Boulder Creek Granite; sp. Silver Plume Granite; mg, microcline gneiss; m, migmatite; bg, biotite gneiss; am, amphibolite; $\square$, dry bulk density, $\Delta$, porosity; $x$, Poisson's ratio; $O$, shear modulus; $\bullet$, bulk modulus. $D$, more feldspathic rocks; $D^{\prime}$, more ferromagnesian rocks. 
The information thus provided may be evaluated in terms of several parameters, so defined as to express quantitatively the engineering properties of the rock. Trial calculations led to the selection of three parameters which seem to best describe the rock behavior in relation to tunneling. These are mean overbreak, roughness factor, and eccentricity. A fourth parameter, percent support, was obtained for larger segments of the tunnel.

Mean overbreak (MO) for a given tunnel interval is calculated as the difference between the area of the payline section (AP) and the area of the arithmetic mean section $(\mathrm{Aa})$ divided by the area of the payline section, the quotient being converted to percent.

$$
M O=\frac{A a-A p}{A p} \times 100
$$

The mean overbreak is, thus, an index of the volume of rock excavated beyond the payline.

The roughness factor $(R)$ for a tunnel interval is defined as the percent difference between the area enclosed by the payline and the area $(\mathrm{Am})$ enclosed by a composite section giving the maximum radius obtained for each $10^{\circ}$ of arc in the tunnel interval.

$$
R=\frac{A m-A p}{A p} \times 100
$$

If transparent plots of all of the tunnel sections for the interval were superimposed, a composite section defining the extent to which each section protrudes beyond the others will have an area Am. This section is referred to on plates 3,4 , and 5 as "maxima all sections." The term expresses the maximum overbreak observed for each radial direction. A corresponding minimum section approximates the payline, or ideal section. The roughness factor is an expression of the gross irregularities in the tunnel surface as compared to the ideal surface.

It will be noted that in many of the composite sections the mean overbreak is greater in some radial directions than in others, so that the arithmetic mean section is not concentric to the payline section. Thus, a factor of eccentricity $(e)$ is calculated as

$$
e=\frac{a+c}{b+c}-1
$$

where ${ }^{1} c$ is the mean radius of the payline section and $a$ and $b$ are respectively the maximum and

\footnotetext{
${ }^{1}$ If $c$ were constant, it could be eliminated from the calculation. However, $c$ has one value for unsupported (rock) sections and other values for supported sections, depending on the type of support used.
}

minimum differences obtained by comparing radii of the arithmetic mean section and the payline section for each $10^{\circ}$ of arc. We may assume that for a homogeneous rock with perfect isotropy, if drilling and blasting were properly executed, the arithmetic mean section would be concentric to the payline section, regardless of the amount of mean overbreak. For such a condition, $a=b$, and the eccentricity is zero. The eccentricity is, thus, an index of the anisotropy of mean overbreak because it compares the shape of the arithmetic mean section with that of the payline section.

Roughness factor and eccentricity are refinements of the overbreak parameter. Together, these parameters serve to define the response of the rock mass to blasting.

Average values for roughness factor, eccentricity, and mean overbreak are given in table 2 for each of the rock types encountered in the 21 selected tunnel intervals. The compilation suggests a significant correlation between rock type and engineering properties. It also indicates that the values for these parameters are consistently higher in supported than in unsupported rock.

TABLE 2.-Engineering properties in relation to rock type

\begin{tabular}{|c|c|c|c|c|}
\hline Rock type & Support ${ }^{1}$ & $\begin{array}{l}\text { Roughness } \\
\text { factor }\end{array}$ & Eccentricity & $\begin{array}{c}\text { Percent mean } \\
\text { overbreak }\end{array}$ \\
\hline $\begin{array}{l}\text { Biotite gneiss } \\
\text { and } \\
\text { schist }\end{array}$ & $\begin{array}{l}\mathbf{R} \\
\mathbf{S} \\
\mathbf{A}\end{array}$ & $\begin{array}{l}32.82 \\
45.92 \\
41.55\end{array}$ & $\begin{array}{r}0.055 \\
.136 \\
.109\end{array}$ & $\begin{array}{l}15.91 \\
18.38 \\
17.55\end{array}$ \\
\hline Migmatite & $\begin{array}{l}\mathbf{R} \\
\mathbf{S} \\
\mathbf{A}\end{array}$ & $\begin{array}{l}35.18 \\
35.18\end{array}$ & $\begin{array}{l}.049 \\
.049\end{array}$ & $\begin{array}{l}12.40 \\
12.40\end{array}$ \\
\hline Amphibolite & $\begin{array}{l}\mathbf{R} \\
\mathbf{S} \\
\mathbf{A}\end{array}$ & $\begin{array}{l}27.47 \\
51.49 \\
39.84\end{array}$ & $\begin{array}{l}.108 \\
.162 \\
.135\end{array}$ & $\begin{array}{l}11.42 \\
25.30 \\
18.36\end{array}$ \\
\hline $\begin{array}{l}\text { All layered or } \\
\text { schistose } \\
\text { rocks }\end{array}$ & $\begin{array}{l}\mathbf{R} \\
\mathbf{S} \\
\mathbf{A}\end{array}$ & $\begin{array}{l}31.04 \\
43.65 \\
39.06\end{array}$ & $\begin{array}{l}.073 \\
.115 \\
.102\end{array}$ & $\begin{array}{l}14.41 \\
17.66 \\
16.69\end{array}$ \\
\hline $\begin{array}{l}\text { Microcline } \\
\text { gneiss }\end{array}$ & $\begin{array}{l}\mathbf{R} \\
\mathbf{S} \\
\mathbf{A}\end{array}$ & $\begin{array}{l}24.89 \\
26.04 \\
25.27\end{array}$ & $\begin{array}{l}.053 \\
.089 \\
.065\end{array}$ & $\begin{array}{r}8.88 \\
12.04 \\
9.93\end{array}$ \\
\hline $\begin{array}{l}\text { Boulder Creek } \\
\text { Granite }\end{array}$ & $\begin{array}{l}\mathbf{R} \\
\mathbf{S} \\
\mathbf{A}\end{array}$ & $\begin{array}{l}20.38 \\
30.89 \\
26.63\end{array}$ & $\begin{array}{l}.072 \\
.085 \\
.080\end{array}$ & $\begin{array}{r}6.09 \\
14.53 \\
11.15\end{array}$ \\
\hline $\begin{array}{l}\text { Silver Plume } \\
\text { Granite }\end{array}$ & $\begin{array}{l}\mathbf{R} \\
\mathbf{S} \\
\mathbf{A}\end{array}$ & $\begin{array}{l}29.40 \\
32.13 \\
30.77\end{array}$ & $\begin{array}{l}.140 \\
.053 \\
.097\end{array}$ & $\begin{array}{r}9.68 \\
11.00 \\
10.34\end{array}$ \\
\hline Pegmatite & $\begin{array}{l}\mathbf{R} \\
\mathbf{S} \\
\mathbf{A}\end{array}$ & $\begin{array}{l}29.10 \\
29.10\end{array}$ & $\begin{array}{r}.060 \\
.060\end{array}$ & $\begin{array}{l}10.38 \\
10.38\end{array}$ \\
\hline $\begin{array}{l}\text { All granitic } \\
\text { rocks }\end{array}$ & $\begin{array}{l}\mathbf{R} \\
\mathbf{S} \\
\mathbf{A}\end{array}$ & $\begin{array}{l}24.84 \\
30.17 \\
27.26\end{array}$ & $\begin{array}{l}.075 \\
.079 \\
.077\end{array}$ & $\begin{array}{r}8.33 \\
13.33 \\
10.60\end{array}$ \\
\hline
\end{tabular}

[Support: $R$, average for rock (unsupported) sections; $S$, average for steel supported sections; A, average for all sections] 
TABLE 3.-Steel supports in relation to rock units

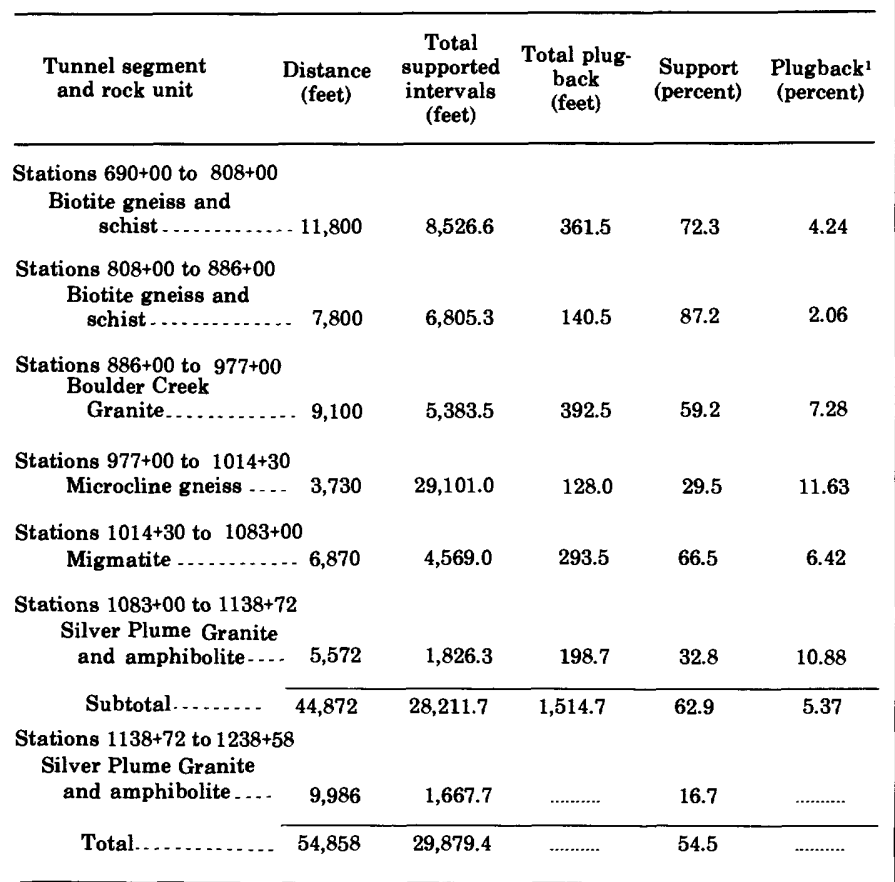

${ }^{1}$ Total plugback/total supported interval.

Percent support was calculated for larger segments of the tunnel that were confined to a particular rock type or lithologic unit (table 3). Supported sections are shown graphically on plate 1 .

Because the change to a rock condition which requires support is transitional, ideal boundaries for beginning and ending a supported section were difficult to establish at the time of excavation. The difficulty is compounded by the fact that the size of the bore must be larger in supported rock than in unsupported rock. The tendency was to delay the change from an unsupported to a supported section until the condition of the rock was obvious. On approaching rock that required support, the unsupported section was commonly extended through the transition zone. Subsequently, it was necessary in most instances to "plugback" (enlarge the opening) through this zone and install supports. Comparison of the several tunnel segments reveals that, relative to the distances involved, the number of supported intervals increases with decrease in total support. The inverse relationship between percent support and percent plugback indicated in table 3 is thus explained.

The relationship of percent support to roughness factor, mean overbreak, and eccentricity in each of the major rock units is shown graphically in figure 10. The graphs suggest that the other engineering

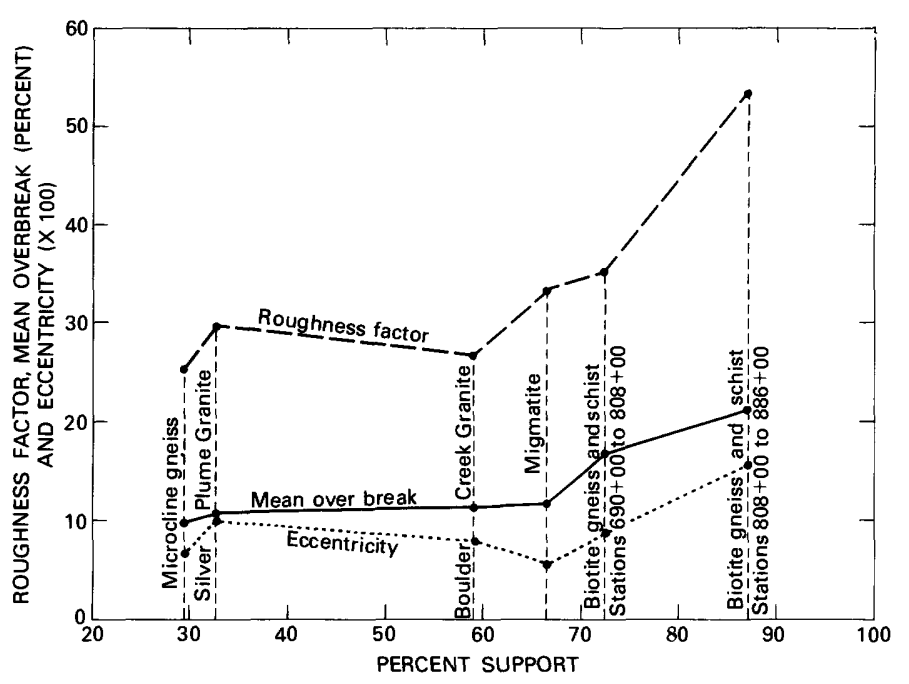

Figure 10.-Percent support in relation to other engineering properties for rock units, Roberts Tunnel.

properties tend to increase generally in the schistose rocks with increase in percent support. However, the tendency does not appear to hold for the granitoid rocks.

\section{GEOLOGICAL PARAMETERS}

One of the readily obtained geological parameters of a rock is its mineral mode, from which, if needed, the chemical composition may be estimated. The preceding discussion suggests a relationship between mineralogy, rock behavior, and engineering problems. Data given in table 1 indicate that the rock types encountered in the eastern half of the Roberts Tunnel show an appreciable range of values for density and elastic constants. These differences in physical properties might be anticipated to result mainly from a combination of differences in the properties of the minerals that compose the rocks. Comparison of tables of modes with table 1 is of interest in this connection. Although Silver Plume Granite, Boulder Creek Granite, and microcline gneiss are markedly similar in modal composition, they show significant differences in physical properties. There are, furthermore, differences in the mechanical behavior of these rocks as reflected in support requirements during tunnel construction (table 3). Evidently, the mechanical behavior of a rock cannot be estimated with confidence on the basis of its modal composition alone. The properties of the rock are not necessarily the combined properties of the constituent minerals. Textural and structural factors, including rock fabric, grain size, and the nature and extent of fracturing in the rock, must also be cónsidered. 
Most of the Precambrian rocks show a discernible planar fabric (foliation), which is caused mainly by preferred orientation of biotite. The linear fabric is well developed at only a few places and is ignored in this discussion. The orientation of the fabric plane with respect to the tunnel axis changes markedly along the route of the tunnel. This orientation may be stated in terms of angular coordinates $-\phi$ and $\rho-$ where $\phi$ is the apparent dip of the fabric plane in a section normal to the tunnel axis and $\rho$ is the least angle between the fabric plane and the tunnel axis. Like dip and strike, $\phi$ and $\rho$ are independent of each other, but together they fix the attitude of the fabric plane. Values for $\phi$ and $\rho$ may be determined by orthographic or stereographic projection from measured attitudes of foliation at selected tunnel stations. The relationships of these values to observed behavior of the rock at these stations, during and after excavation, can then be compared.

Comparison of $\phi$ and $\rho$ values with engineering

TABLE 4.-Relation of planar rock fabric to engineering properties

[Support: S, steel supported; R, rock section-unsupported]

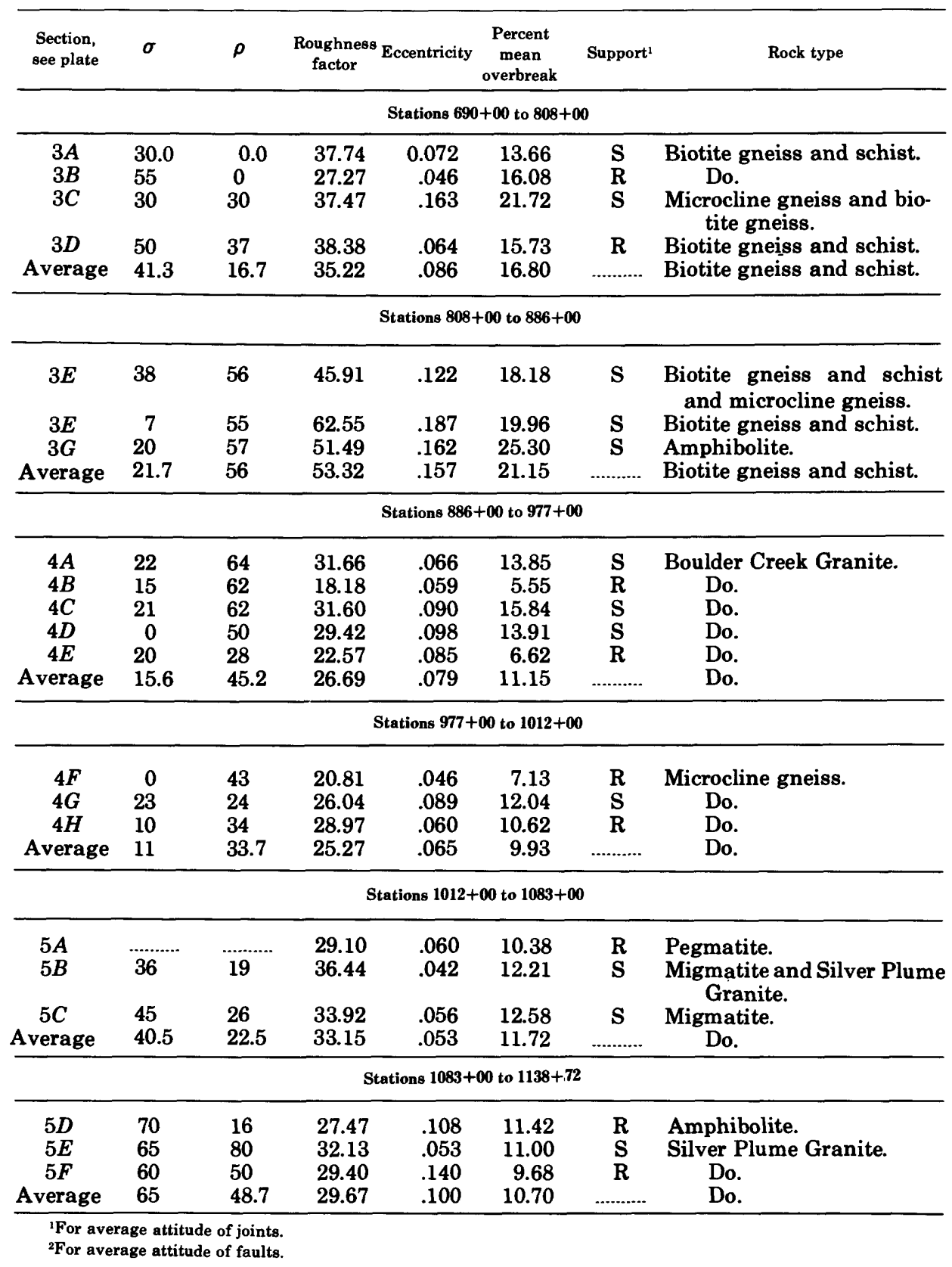



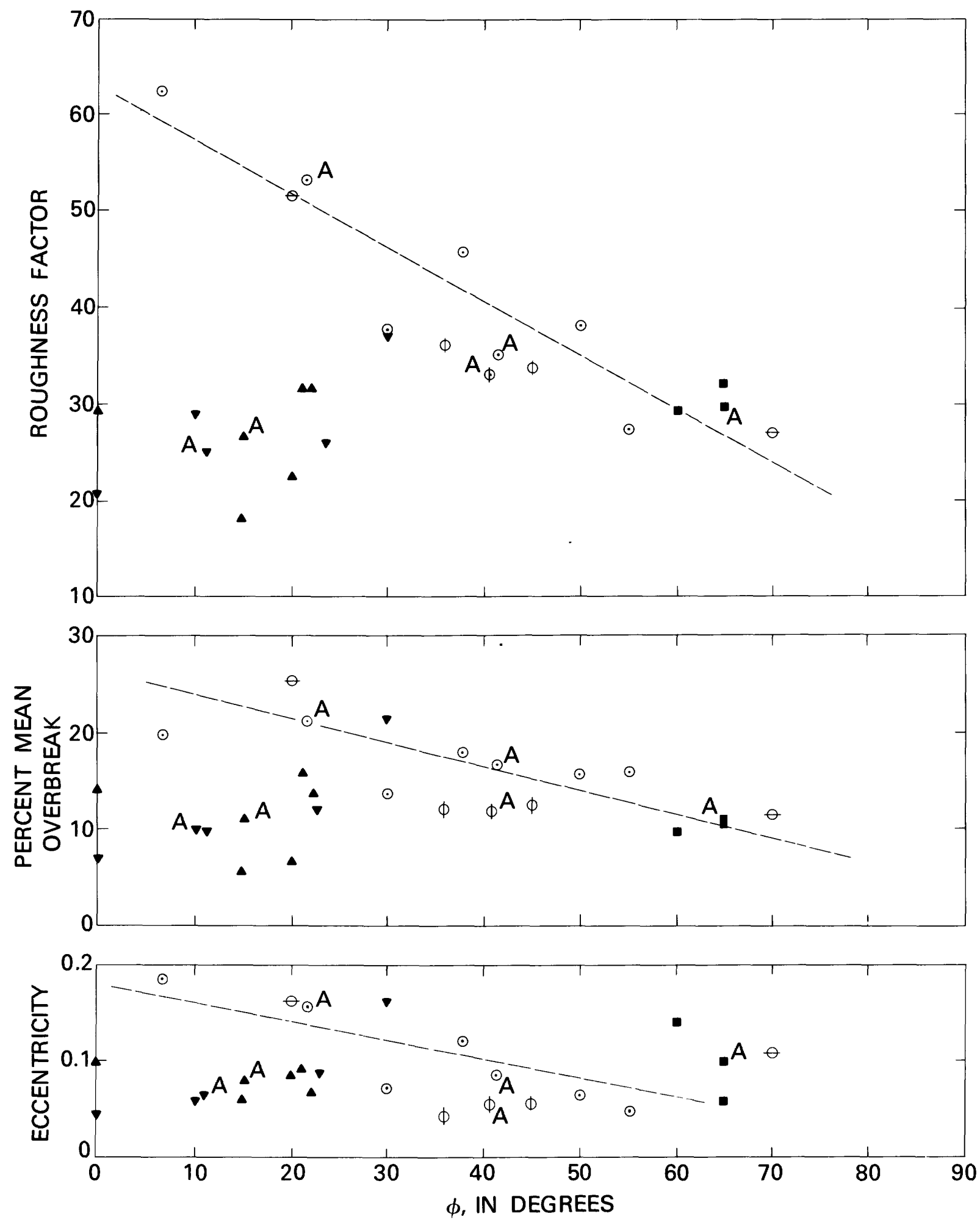

FIGURE 11.-Phi $(\phi)$ in relation to engineering properties of rock types, Roberts Tunnel. Symbols indicate dominant rock type: $\odot$, biotite gneiss and schist; $\phi$, migmatite; $\ominus$, amphibolite; $\nabla$, microcline gneiss; $\triangle$, Boulder Creek Granite; $\square$, Silver Plume Granite; A, average for interval. 

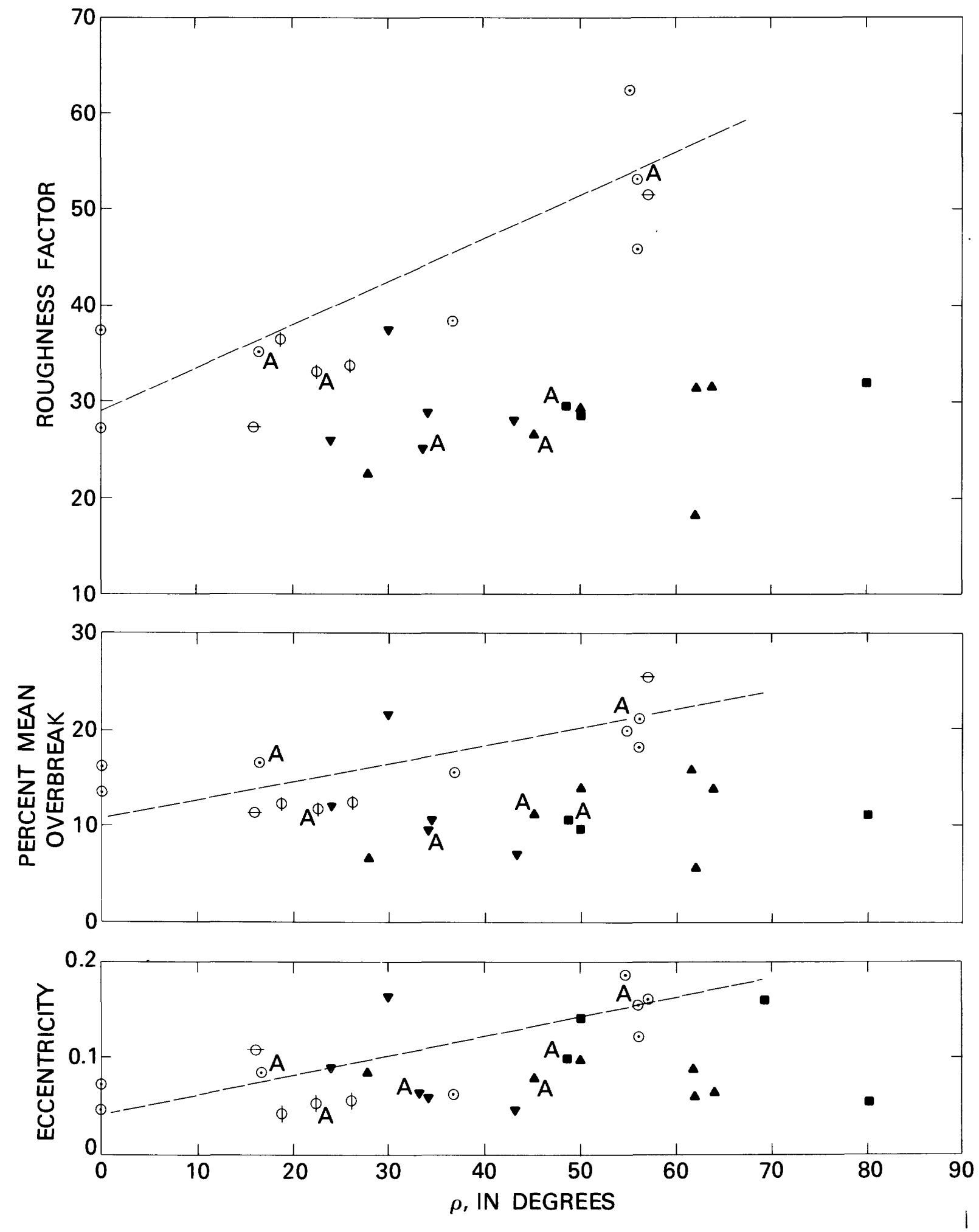

FIGURE 12.-Rho $(\rho)$ in relation to engineering properties of rock types, Roberts Tunnel. Symbols indicate dominant rock type: $\odot$, biotite gneiss and schist; $\phi$, migmatite; $\ominus$, amphibolite; $\nabla$, microcline gneiss; $\wedge$, Boulder Creek Granite; $\square$, Silver Plume Granite; A, average for interval. 
properties for the 21 selected test intervals in the southeastern part of the Roberts Tunnel is provided in table 4. The data are graphed separately for $\phi$ and $\rho$ in figures 11 and 12 , respectively. Values for roughness factor, mean overbreak, and eccentricity show, in general, a direct relationship to $\rho$ and an inverse relationship to $\phi$. These relationships do not hold for the poorly foliated rocks.

The possibility that the technique may apply to prominent fracture planes, as well as to foliation, was considered. Unfortunately, regular sets of joints and faults were observed in only two of the text intervals, both in Silver Plume Granite. (See table 4, secs. for pl. $5 E, F$.) These data are, therefore, inconclusive.

The attitudes of 568 faults and 1,326 joints were measured between the East Portal (sta. 1238+58) and station $690+00$. Only joints and faults that could be traced across the tunnel or projected a comparable distance, were included in the study. The spacing, attitudes, and character of the fractures change with locality and rock type. Four parameters were devised to quantify the data in order to evaluate these changes and relate them to other factors. The parameters chosen were joint density, fault density, faultjoint ratio, and joint anisotropy.

Joint density, as used in this report, refers to the number of joints per 100-foot interval of tunnel. An average value for a thick rock unit is obtained by dividing the length of the tunnel through the unit, measured in hundreds of feet, into the number of joints recorded along this length. Fault density is determined in the same manner. The fault-joint ratio is the fault density divided by the joint density.

Joint anisotropy is an index of the tendency for the joints in a given rock unit or tunnel interval to be concentrated into one or more sets. The tendency is expressed as a concentration of joint poles on an equal-area plot, leaving some parts of the diagram outside a zero contour. The combined area of these parts can be measured with a planimeter and calculated as a percentage of the total area. This value effectively expresses the anisotropy of the joint pattern. For a perfectly isotropic distribution of poles, the value would be zero. The technique was not applied to faults in this study because of their scarcity in some of the rock units.

The four fracture parameters are compared with engineering data for each of the major rock units in table 5. Trial plots using various combinations of fracture parameters and engineering parameters indicated that among the engineering parameters, the fracture parameters correlate best with percent support. The joint parameters and fault parameters are shown separately in relation to percent support in figures 13 and 14 , respectively. Values for fault density (fig. 14A), fault-joint ratio (fig. 14B), and joint anisotropy (fig. 13B) appear to vary directly; whereas values for joint density (fig. 13A) appear to vary inversely, with percent support. The plots for two rock types, microcline gneiss and Silver Plume Granite (with admixed amphibolite) show poor fits on all the diagrams. It is of interest to note that for these rocks the elastic moduli are appreciably larger than for the other rock types (fig. 9B).

TABLE 5.-Summary of fracture parameters and engineering data for rock units

\begin{tabular}{|c|c|c|c|c|c|c|c|c|c|c|c|c|c|c|c|}
\hline \multirow{2}{*}{ Rock unit } & \multirow{2}{*}{$\begin{array}{l}\text { Station } \\
\text { interval }\end{array}$} & \multirow{2}{*}{$\begin{array}{l}\text { Distance } \\
\text { in } 100 \\
\text { feet }\end{array}$} & \multirow{2}{*}{$\begin{array}{c}\text { Number } \\
\text { joints }\end{array}$} & \multicolumn{3}{|c|}{ Number faults } & \multirow{2}{*}{$\begin{array}{c}\text { Joint } \\
\text { density }\end{array}$} & \multirow{2}{*}{$\begin{array}{c}\text { Fault } \\
\text { density }\end{array}$} & \multirow{2}{*}{$\begin{array}{l}\text { Fault- } \\
\text { joint } \\
\text { ratio }\end{array}$} & \multirow{2}{*}{$\begin{array}{l}\text { Joint } \\
\text { aniso- } \\
\text { tropy }\end{array}$} & \multirow{2}{*}{$\begin{array}{l}\text { Support } \\
\text { (percent) }\end{array}$} & \multirow{2}{*}{$\begin{array}{c}\text { Progress } \\
\text { in feet } \\
\text { per report } \\
\text { period }\end{array}$} & \multirow{2}{*}{$\begin{array}{l}\text { Rough- } \\
\text { ness }\end{array}$} & \multirow{2}{*}{$\begin{array}{l}\text { Eccen- } \\
\text { tricity }\end{array}$} & \multirow{2}{*}{$\begin{array}{c}\text { Mean } \\
\text { over- } \\
\text { break }^{1}\end{array}$} \\
\hline & & & & Major & Minor & Total & & & & & & & & & \\
\hline $\begin{array}{l}\text { Biotite } \\
\text { gneiss } \\
\text { and } \\
\text { schist }\end{array}$ & $\begin{array}{l}690+00 \text { to } 720+00 \\
720+00 \text { to } 750+00 \\
750+00 \text { to } 808+00 \\
690+00 \text { to } 808+00 \\
808+00 \text { to } 886+00\end{array}$ & $\begin{array}{r}30.0 \\
30.0 \\
58.0 \\
118.0 \\
78.0\end{array}$ & $\begin{array}{r}134 \\
123 \\
98 \\
355 \\
115\end{array}$ & $\begin{array}{r}3 \\
1 \\
11 \\
15 \\
22\end{array}$ & $\begin{array}{r}195 \\
49 \\
80 \\
195 \\
98\end{array}$ & $\begin{array}{r}69 \\
50 \\
91 \\
210 \\
120\end{array}$ & $\begin{array}{l}4.47 \\
4.10 \\
1.69 \\
3.01 \\
1.47\end{array}$ & $\begin{array}{l}2.30 \\
1.67 \\
1.57 \\
1.78 \\
1.54\end{array}$ & $\begin{array}{r}0.51 \\
.41 \\
.93 \\
.59 \\
1.05\end{array}$ & $\begin{array}{l}46.9 \\
58.0 \\
61.6 \\
31.2 \\
45.1\end{array}$ & $\begin{array}{l}72.6 \\
72.3 \\
71.9 \\
72.3 \\
87.2\end{array}$ & $\begin{array}{l}502.4 \\
433.3 \\
441.7 \\
453.4 \\
559.4\end{array}$ & $\begin{array}{l}\cdots \\
\cdots \cdots \\
\cdots \\
35.2 \\
53.3\end{array}$ & $\begin{array}{r}\cdots \\
0.086 \\
.157\end{array}$ & $\begin{array}{l}\ldots \ldots \\
\ldots \ldots \\
16.8 \\
21.2\end{array}$ \\
\hline $\begin{array}{l}\text { Boulder } \\
\text { Creek } \\
\text { Granite }\end{array}$ & $\begin{array}{l}886+00 \text { to } 915+00 \\
915+00 \text { to } 945+00 \\
945+00 \text { to } 977+00 \\
886+00 \text { to } 977+00\end{array}$ & $\begin{array}{l}29.0 \\
30.0 \\
32.0 \\
91.0\end{array}$ & $\begin{array}{r}189 \\
98 \\
149 \\
436\end{array}$ & $\begin{array}{l}0 \\
3 \\
3 \\
6\end{array}$ & $\begin{array}{r}8 \\
16 \\
19 \\
43\end{array}$ & $\begin{array}{r}8 \\
19 \\
22 \\
49\end{array}$ & $\begin{array}{l}6.52 \\
3.27 \\
4.66 \\
4.79\end{array}$ & $\begin{array}{l}.28 \\
.63 \\
.68 \\
.54\end{array}$ & $\begin{array}{l}.04 \\
.19 \\
.15 \\
.11\end{array}$ & $\begin{array}{r}33.3 \\
51.7 \\
30.2 \\
8.8\end{array}$ & $\begin{array}{l}56.6 \\
63.3 \\
57.6 \\
59.2\end{array}$ & $\begin{array}{l}801.4 \\
707.0 \\
729.4 \\
738.2\end{array}$ & ... & $\begin{array}{l}\cdots \\
\cdots \\
\cdots \\
.079\end{array}$ & $\begin{array}{l}\cdots \\
\cdots \\
\cdots \\
11.2\end{array}$ \\
\hline $\begin{array}{l}\text { Microcline } \\
\text { gneiss } \\
\text { Migmatite }\end{array}$ & $\begin{array}{r}977+00 \text { to } 1014+30 \\
1014+30 \text { to } 1083+00\end{array}$ & $\begin{array}{l}37.3 \\
68.7\end{array}$ & $\begin{array}{l}165 \\
106\end{array}$ & $\begin{array}{l}2 \\
9\end{array}$ & $\begin{array}{r}5 \\
37\end{array}$ & $\begin{array}{r}7 \\
48\end{array}$ & $\begin{array}{l}4.42 \\
1.54\end{array}$ & $\begin{array}{l}.19 \\
.70\end{array}$ & $\begin{array}{l}.04 \\
.45\end{array}$ & $\begin{array}{l}43.9 \\
53.0\end{array}$ & $\begin{array}{l}29.5 \\
66.5\end{array}$ & $\begin{array}{l}737.3 \\
691.1\end{array}$ & $\begin{array}{l}25.3 \\
33.2\end{array}$ & $\begin{array}{l}.065 \\
.053\end{array}$ & $\begin{array}{r}9.9 \\
11.4\end{array}$ \\
\hline $\begin{array}{l}\text { Silver Plume } \\
\text { Granite and } \\
\text { amphibolite }\end{array}$ & $1083+00$ to $1138+72$ & $2 \quad 55.7$ & 126 & 13 & 23 & 36 & 2.26 & .65 & .29 & 66.8 & 32.8 & 600.9 & 29.7 & .100 & 10.7 \\
\hline
\end{tabular}

${ }^{1}$ Average values from table 4. 

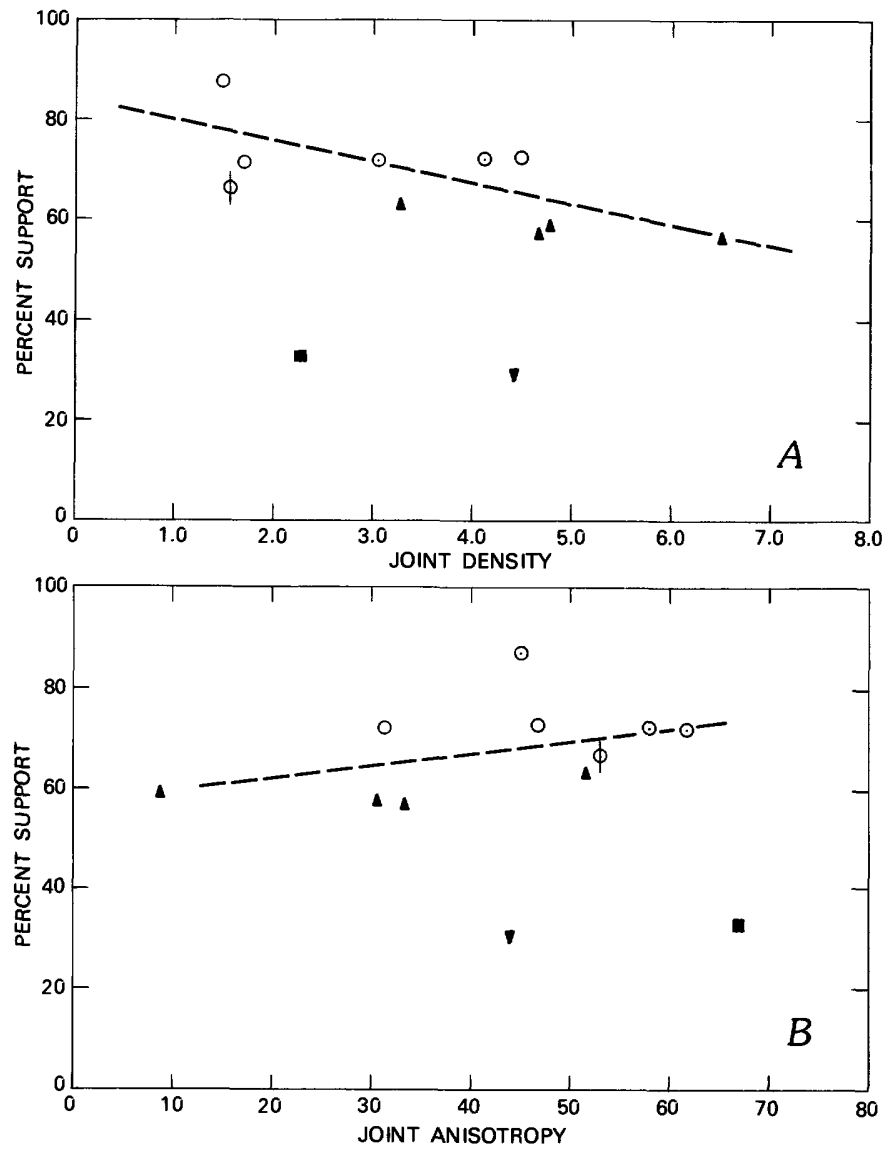

FIGURE 13.-Joint parameters in relation to percent support for rock units, Roberts Tunnel. Symbols indicate dominant rock type: $\odot$, biotite gneiss and schist; $\phi$ migmatite; $\nabla$, microcline gneiss; 4 , Boulder Creek Granite; $\mathbf{n}$, Silver Plume Granite.

\section{DISCUSSION OF RESULTS}

Comparison of figures $9 B$ and 10 indicates that percent support values for various rock types bear a rough inverse relationship to values for the principal elastic constants. In terms of percent support, the major rock units tend to fall into two distinct groups: granitoid rocks and schistose rocks. The schistose rocks have a distinctly higher biotite content and have higher support requirements than granitoid rocks. The difference is less well defined in terms of elastic moduli.

The position of the Boulder Creek Granite is anomalous in that it relates more closely to the schistose rocks than to Silver Plume Granite. A possible reason for this is the proximity of the Boulder Creek pluton to the North Fork fault zone. Fault density and fault-joint ratio are lower for Boulder Creek Granite, however, than for Silver Plume Granite (table 5; fig. 14), which suggests that faulting alone does not account for the difference in
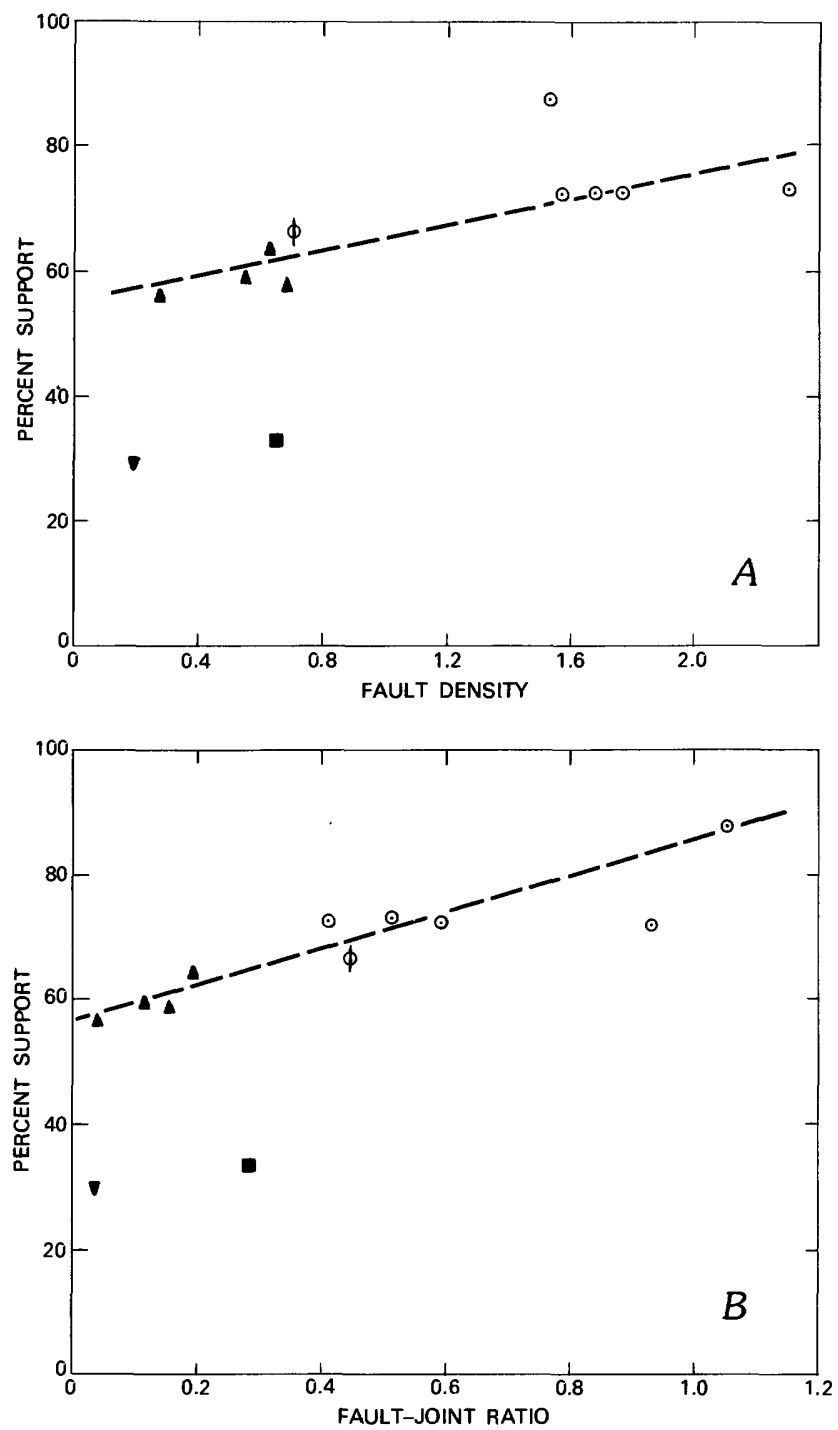

FIGURE 14.-Fault parameters in relation to percent support for rock units, Roberts Tunnel. Symbols indicate dominant rock type: $\odot$, biotite gneiss and schist; $\Phi$, migmatite; $\nabla$, microcline gneiss; 4 , Boulder Creek Granite; $\square$, Silver Plume Granite.

behavior of the two rocks. A more probable explanation lies in the somewhat greater susceptibility of the Boulder Creek Granite to hydrothermal alteration, which is related to its higher biotite content and the more calcic nature of its plagioclase. Thin section studies of Boulder Creek and Silver Plume Granite samples from the tunnel indicate that the Boulder Creek Granite is more altered, even where both appear equally fresh in hand specimen. The alteration may be presumed to account for the abnormally low moduli of elasticity for the Boulder Creek Granite and a corresponding loss of strength as reflected in its support requirement. Microcline gneiss, although similar in modal composition to 
Boulder Creek Granite, is less altered, perhaps because of its finer texture and lower permeability.

The relationships of other engineering parameters to rock type and elastic constants are more complex. Values for roughness factor, mean overbreak, and eccentricity are nearly the same for all granitoid rock types, regardless of support requirement, whereas these values increase appreciably with increase in percent support for the schistose rocks. Fabric is thus an important factor in the engineering behavior of the rock.

Among the well-foliated rocks, values of roughness factor, mean overbreak, and eccentricity vary directly with $\rho$ and are least where $\rho$ is zero; that is, where the foliation is parallel to the tunnel axis (fig. 11). Conversely, the values for these parameters vary inversely with $\phi$ and are least where $\phi$ is $90^{\circ}$; that is, where the trace of foliation in the tunnel section is vertical (fig. 10). Apparently, the most favorable combination of $\phi$ and $\rho$ with reference to the parameters mentioned is for vertical foliation parallel to the tunnel axis. For such a condition, the shape and diameter of the rock bore conform most nearly to those desired. Presumably, the condition is one for which the rock is most stable with respect to stresses placed upon it during and after excavation. The same relationship was noted by Wahlstrom (1948, p. 1314) for other tunnels in foliated rocks.

Wahlstrom also noted that progress tends to be slower for tunneling parallel to foliation than across it, a generalization that is supported by data from the Roberts Tunnel. The progress rate in biotite gneiss is appreciably lower between stations $690+00$ and 808 +00 , where $\rho$ values are low, than between stations $808+00$ and $886+00$, where $\rho$ values are higher. (Compare tables 4 and 5.) The difference, of course, may be due in part to other factors.

Difficulties are encountered in attempting to correlate fracture data with engineering properties for the major rock types. Values for roughness factor, mean overbreak, and eccentricity were obtained from test intervals too short individually to provide enough faults or joints for statistical analysis. Average values for these parameters were obtained for the test intervals in each rock unit and may be compared with fracture data for the unit (table 5). However, the reliability of the comparison may be questioned. A quantitative relationship of fracture data to engineering behavior of the rock units is best shown with regard to percent support (figs. 13, 14).
Although the correlation of joint data with support requirements is poorly defined (fig. 13), the plots appear to show significant trends. Values for joint density and joint anisotropy are not closely related to rock type; there is a range of values for both granitold and schistose rocks, and the ranges overlap.

The need for support appears to decrease with increase in joint density (fig. 13A). A possible explanation is that, in a well-jointed rock, stresses induced by excavation tend to be relieved along joint planes, reducing the tendency for spalling or raveling. This behavior would seem to apply more to massive than to foliated rocks. The trend indicated presumably could be extrapolated to some critical value of joint density beyond which the rock would become weakened by fracturing. Apparently, jointdensity values did not approach this limit in the Roberts Tunnel.

Comparison of percent support with joint anisotropy (fig. 13B) suggests that the support requirement increased somewhat with the tendency of the joints to be grouped into a few well-defined sets. The technique does not take into account the orientation of the joint sets with respect to the tunnel axis. Assuming that the orientation may affect the need for support, the scattering of points on the diagram may be partly explained.

A better correlation is obtained for fault data with percent support (fig. 14). It is of interest to note that values for both fault density and fault-joint ratio are, on the whole, lower for the granitoid rocks than for the schistose rocks. This may be explained by the fact that minor faulting, which accounts for most of the faults, was controlled by foliation. The more massive rocks were affected mainly by the fewer major faults.

The correlation of fault-joint ratio with support is of interest. A comparison of figures $13 A$ and $14 A$ suggests that, within the limits of this study, joints and faults have opposite effects on the ability of rocks to resist stresses induced in underground openings. When the two effects are combined as a ratio, some of the idiosyncrasies common to both apparently cancel out. Figure $14 B$ indicates that the effect of faulting is dominant. Theoretically, the fault-joint ratio could range from zero to infinity. These extremes are approached for very short tunnel intervals, but the values become meaningful only for large intervals of rock. The data suggest that the 
ratio may provide an index to the relative strength of different rock masses in a given stress environment.

A notable feature of figures 13 and 14 is the marked separation of plots for microcline gneiss and Silver Plume Granite from those for the other rock types. As shown previously, these granitoid rocks have distinctly higher values for elastic moduli than the schistose rocks. The diagrams suggest similar but separate trends for the two groups of rock. The tendency of the Boulder Creek Granite to behave as a schistose rock in terms of its support requirement is strikingly illustrated.

\section{REFERENCES CITED}

Blair, P. E., 1955, Physical properties of mine rock, pt. III: U.S. Bur. Mines Rept. Inv. 5130, 69 p.

1956, Physical properties of mine rock, pt. IV: U.S. Bur. Mines Rept. Inv. 5244, 69 p.

Boos, M. F., 1954, Genesis of Precambrian granitic pegmatites in the Denver Mountain Parks area, Colorado: Geol. Soc. America Bull., v. 65, p. 115-142.

Bucky, P. B., chm., 1945, Rock bursts; a symposium: Am. Inst. Mining Engineers Trans., v. 163, p. 568-623.

Buddington, A. F., 1959, Granite emplacement with special reference to North America: Geol. Soc. America Bull., v. 70, p. 617-747.

Cloos, E., 1946, Lineation; a critical review and annotated bibliography: Geol. Soc. America Mem. 18, 122 p.

Fyfe, W. S., Turner, F. J., and Verhoogen, J., 1958, Metamorphic reactions and metamorphic facies: Geol. Soc. America Mem. $73,260 \mathrm{p}$.

Harrison, J. E., and Moench, R. H., 1961, Joints in Precambrian rocks, Central City-Idaho Springs area, Colorado: U.S. Geol. Survey Prof. Paper 374-B, 14 p.

Harrison, J. E., and Wells, J. D., 1956, Geology and ore deposits of the Freeland-Lamartine district, Clear Creek County, Colorado: U.S. Geol. Survey Bull. 1032-B, p. 33-127.

1959, Geology and ore deposits of the Chicago Creek area, Clear Creek County, Colorado: U.S. Geol. Survey Prof. Paper 319, 92 p.

Hutchinson, R. M., $1959, \mathrm{~A}^{40} / \mathrm{K}^{40}$ age determinations of rocks associated with north end of Pikes Peak batholith, Jefferson, Douglas, and Park Counties, Colorado [abs.]: Geol. Soc. America Bull., v. 70, p. 1622.

Judd, W. R., ed., 1964, State of stress in the earth's crust: New York, Am. Elsevier Pub. Co., 732 p.

Lovering, T. S., and Goddard, E. N., 1950, Geology and ore deposits of the Front Range, Colorado: U.S. Geol. Survey Prof. Paper 223, $319 \mathrm{p}$.

Mielenz, R. C., 1955, Petrography and engineering properties of igneous rocks: U.S. Bur. Reclamation Eng. Mon. 1, 19 p.

Moench, R. H., Harrison, J. E., and Sims, P. K., 1962, Precambrian folding in the Idaho Springs-Central City area, Front Range, Colorado: Geol. Soc. America Bull., v. 73, p. 35-58.
Obert, L., Windes, S. L., and Duvall, W. I., 1946, Standardized tests for determining the physical properties of mine rock: U.S. Bur. Mines Rept. Inv. 3891, 67 p.

Olsen, O. J., 1957, Measurement of residual stress by the strain relief method: Colorado School Mines Quart., v. 52, no. 3, p. 184-204.

Robinson, C. S., Lee, F. T., and others, 1974, Engineering geologic, geophysical, and rock-mechanics investigations of the Straight Creek Tunnel site and pilot bore, Colorado: U.S. Geol Survey Prof. Paper 815, 134 p.

Robinson, C. S., Warner, L. A., and Wahlstrom, E. E., 1974, General geology of the Harold D. Roberts Tunnel, Colorado: U.S. Geol. Survey Prof. Paper 831-B, 48 p.

Scott, J. H., Lee, F. T., Caroll, R. D., and Robinson, C. S., 1968, The relationship of geophysical measurements to engineering and construction parameters in the Straight Creek Tunnel pilot bore, Colorado: Int. J. Rock Mech. Min. Sci., v. 5, p. 1-30.

Swain, R. J., 1962, Recent techniques for determination of the in situ elastic properties and measurement of motion amplification in layered media: Geophysics, v. 27, p. 237-241.

Thomas, E., 1962, Stabilization of rock by bolting; in T. Fluhr, and R. F. Leggett, eds., Reviews in engineering geology: Geol. Soc. America, v. 1.

Trimble, J. K., 1960, Geology of the Kenosha Pass area, Park County, Colorado: Colorado School Mines M.S. thesis.

Tweto, O., and Sims, P. K., 1963, Precambrian ancestry of the Colorado mineral belt: Geol. Soc. America Bull., v. 74, p. 991-1014.

Wahlstrom, E. E., 1948, Application of geology to tunneling problems: Am. Soc. Civil Engineers Trans., v. 113, p. 1310-1348.

1974, History of geologic investigations, engineering design, and construction methods of the Harold D. Roberts Tunnel, Colorado: U.S. Geol. Survey Prof. Paper 831-A, 13 p.

1981, Summary of the engineering geology of the Harold D. Roberts Tunnel, Colorado: U.S. Geol. Survey Prof. Paper 831-E, $15 \mathrm{p}$.

Wahlstrom, E. E., and Kim, O. J., 1959, Precambrian rocks of the Hall Valley area, Front Range, Colorado: Geol. Soc. America Bull., v. 70, p. 1217-1244.

Wahlstrom, E. E., Robinson, C. S., and Hornback, V. Q., 1981, Geology of the western part of the Harold D. Roberts Tunnel, Colorado (Stations $0+00$ to $690+00$ ): U.S. Geol. Survey Prof. Paper 831-C, 58 p.

Warner, L. A., and Robinson, C. S., 1967, Geology of the Harold D. Roberts Tunnel, Colorado; Station $408+49$ to east portal: Geol. Soc. America Bull., v. 78, p. 87-120.

White, W. S., 1946, Rock bursts in the granite quarries at Barre, Vermont: U.S. Geol. Survey Circ. 13, 15 p.

Windes, S. L., 1949, Physical properties of mine rock, pt. I: U.S. Bur. Mines Rept. Inv. 4459, 79 p.

1950, Physical properties of mine rock, pt. II: U.S. Bur. Mines Rept. Inv. 4727, $37 \mathrm{p}$.

Wuerker, R. G., 1956, Annotated tables of strength and elastic properties of rocks: Am. Inst. Mining Engineers, Petroleum Branch, Paper no. 663-G, 12 p., 5 tables. 

